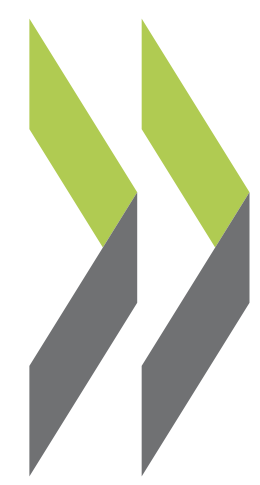

OECD Science, Technology and Industry Working Papers 2009/02

OECD Work on Innovation A Stocktaking of Existing Sarah Box Work 
Organisation de Coopération et de Développement Économiques

Organisation for Economic Co-operation and Development

02-Feb-2009

DIRECTORATE FOR SCIENCE, TECHNOLOGY AND INDUSTRY

English text only

OECD WORK ON INNOVATION - A STOCKTAKING OF EXISTING WORK

STI WORKING PAPER 2009/2

Science and Technology Policy

Sarah BOX (OECD) 


\title{
OECD WORK ON INNOVATION - A STOCKTAKING OF EXISTING WORK
}

\author{
Sarah Box ${ }^{1}$, OECD
}

\begin{abstract}
In May 2007, OECD Ministers mandated the preparation of an OECD Innovation Strategy. The Strategy has two broad aims: first, addressing countries' needs for a more comprehensive, coherent and timely understanding of how to promote, measure and assess innovation and its underlying dynamics of change; and, second, shedding light on appropriate multi-sector and whole-of-government approaches to innovation as a driver of sustainable growth, productivity and development and as a tool to address global challenges. Work on the Strategy is to take place over 2008-09, with a synthesis report to be delivered to the Ministerial Council Meeting in 2010.

This paper forms part of the first phase of work on the Innovation Strategy. It draws on OECD work from the last ten years to provide a broad-brush overview of "what we know" about good policy practices for innovation. It also highlights recent changes in innovation processes and patterns, describes the increasing levels of internationalisation, and draws together early thinking on the contribution of innovation to solving global challenges related to the environment.

The stocktaking highlights that much work, both theoretical and empirical, has already been done to identify the policies, institutions and framework conditions that can provide the most effective means of supporting innovation. However, evaluation of specific government support policies and their impacts on innovation is generally sparse and there is a need for more and better evidence on the costs and benefits of government support for innovation. Measurement of innovation is also an area where further work is likely to yield benefits, particularly in better understanding innovation in the service sector and better capturing the increasingly international nature of innovation activities. Finally, forming a robust approach to the governance arrangements around multi-country challenges, such as climate change and water, will be essential to leverage the impact of national efforts and ensure all countries can gain from the fruits of innovation.
\end{abstract}

1. This paper was prepared as a background document for the "Stocktaking Workshop on the OECD Innovation Strategy", held at OECD Headquarters on 23 June 2008. It was based on analyses prepared across the OECD related to innovation, and valuable input was received from OECD Directorates including CFE, DAF, ECO, EDU, ELS, ENV, GOV and TAD. The author would like to thank Mario Cervantes and Dirk Pilat from the Science and Technology Policy Division of the Directorate for Science, Technology and Industry for their comments and inputs. 
DSTI/DOC(2009)2

\title{
TRAVAUX DE L'OCDE SUR L'INNOVATION - ÉTAT DES LIEUX
}

\author{
Sarah Box ${ }^{2}$ OCDE
}

\section{RESUME}

En mai 2007, les ministres de l'OCDE ont prescrit l'élaboration d'une Stratégie de l'OCDE pour l'innovation, axée sur deux objectifs majeurs : 1) répondre aux besoins des pays qui souhaitent avoir une vision plus précise, plus cohérente et plus actuelle de la façon dont ils pourraient promouvoir, mesurer et évaluer l'innovation et la dynamique du changement qui la sous-tend, et 2) mettre en lumière des approches multisectorielles, englobant tous les niveaux d'administration, capables de faire de l'innovation un vecteur de croissance, de productivité et de développement durables et de contribuer à la résolution des problèmes mondiaux. Les travaux relatifs à la Stratégie se dérouleront sur la période 2008-2009 et un rapport de synthèse sera publié lors de la Réunion du Conseil au niveau des Ministres en 2010.

Le présent rapport s'inscrit dans le cadre de la première phase de travail sur la Stratégie pour l'innovation. Il s'appuie sur les travaux menés par l'OCDE au cours des dix dernières années afin de faire un rapide tour d'horizon des connaissances existantes sur les pratiques exemplaires en matière de politiques de soutien à l'innovation. Il met également en évidence l'évolution récente des processus et des modèles d'innovation, explique l'internationalisation croissante de l'innovation et réunit les premières théories sur le rôle de l'innovation dans la résolution des défis liés à l'environnement au niveau mondial.

Le rapport souligne qu'un travail important, tant sur le plan théorique qu'empirique, a déjà été réalisé pour identifier les politiques, les institutions et les conditions-cadres les mieux à même de soutenir l'innovation. Néanmoins, l'évaluation des politiques publiques ciblées et de leurs conséquences sur l'innovation reste limitée : il est aujourd'hui nécessaire de recueillir davantage de données plus précises sur les coûts et les avantages de l'aide publique à l'innovation. L'approfondissement des travaux menés dans le domaine de la mesure de l'innovation devrait également porter ses fruits, en permettant par exemple de mieux comprendre l'innovation dans le secteur des services et de mieux saisir la dimension internationale croissante des activités d'innovation. Enfin, l'élaboration d'une stratégie solide à l'égard des dispositifs de gouvernance mis en place pour relever les défis mondiaux, comme le changement climatique et l'approvisionnement en eau, sera indispensable pour optimiser l'impact des efforts nationaux et pour veiller à ce que tous les pays soient en mesure de récolter les fruits de l'innovation.

2. Ce rapport figure parmi les documents de référence destinés à l'atelier «Stocktaking Workshop on the OECD Innovation Strategy » organisé au siège de l'OCDE le 23 juin 2008. Il s'appuie sur les travaux menés à l'échelle de l'OCDE dans le domaine l'innovation, notamment sur les contributions précieuses des différentes directions de l'Organisation comme CFE, DAF, ECO, EDU, ELS, ENV, GOV et TAD. L'auteur tient à remercier Mario Cervantes et Dirk Pilat de la Division de la politique scientifique et technologique de la DSTI pour leurs commentaires et leur contribution. 


\section{TABLE OF CONTENTS}

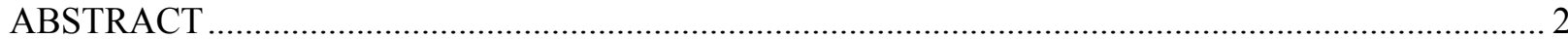

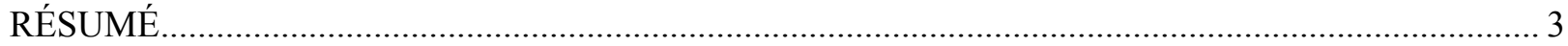

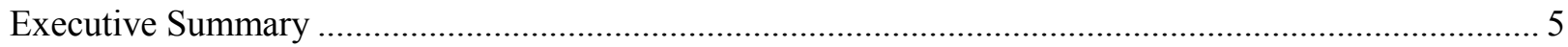

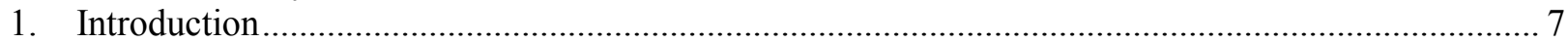

2. Innovation, growth and the rationale for government intervention …............................................ 7

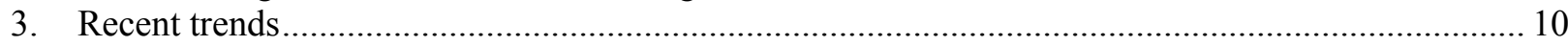

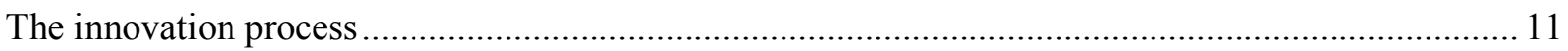

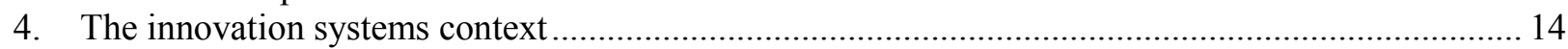

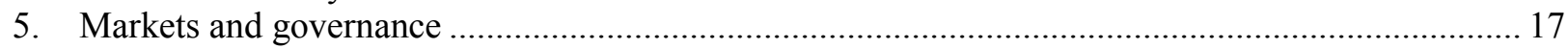

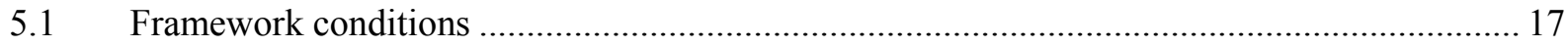

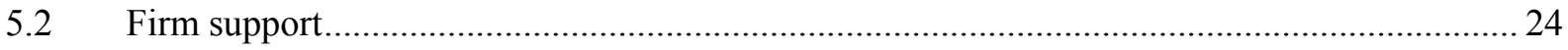

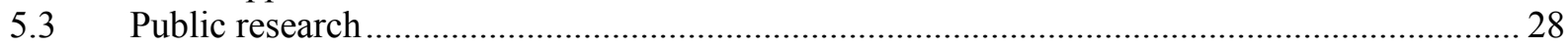

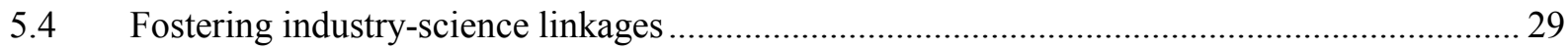

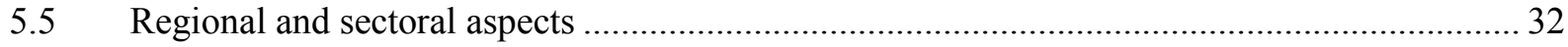

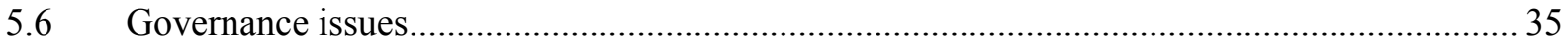

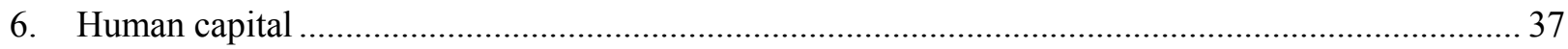

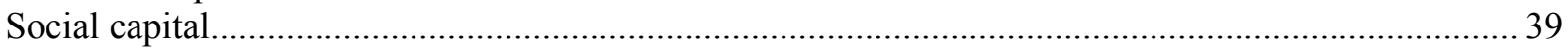

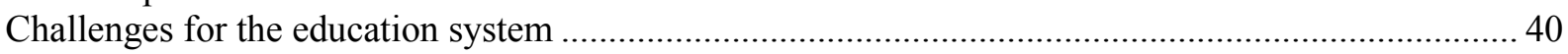

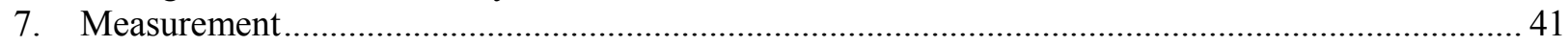

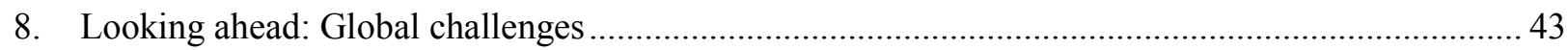

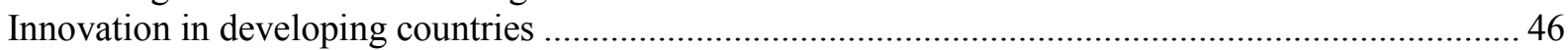

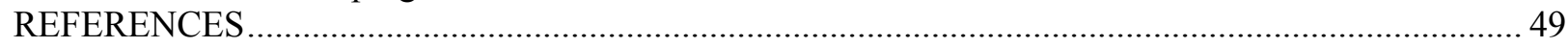




\section{EXECUTIVE SUMMARY}

This paper forms part of the first phase of work on the OECD Innovation Strategy. It draws on OECD work from the last ten years to provide a broad-brush overview of "what we know" about good policy practices for innovation. It also highlights recent changes in innovation processes and patterns, describes the increasing levels of internationalisation, and draws together early thinking on the contribution of innovation to solving global challenges related to the environment.

What emerges from this stocktaking exercise? And what does it mean for carrying out work for the Innovation Strategy? One general message is that innovation operates and flourishes through a range of market and non-market interactions. As such there is a clear role for government policy in ensuring economic conditions to foster innovation (i.e. framework conditions) but also in addressing market failures that limit or inhibit the social and economic benefits from innovation. However, it is important that policy does not simply focus on supporting the creation of new knowledge - better using the existing stock of knowledge is essential for maximising the gains from innovation and, indeed, many countries rely heavily on the adoption of innovations from abroad for their own innovation performance. Similarly, the focus should be on maximising the benefits of the public resources used to support innovation, rather than maximising those resources themselves.

The stocktaking highlighted that much work, both theoretical and empirical, has already been done to identify the particular policies, institutions and framework conditions that can provide the most effective means of supporting innovation.

- For framework conditions, it is clear that macroeconomic stability, openness to trade and investment, deep financial systems, competitive markets, and regulation that is proportionate and appropriate will best support innovative activity. Labour markets that allow mobility and adjustment, assist workers to retrain, and allow firms to undertake organisational change, are important. Flatter, lower and more predictable taxes are also shown to have positive influences on innovation. Intellectual property rights are more complex, with a balance to be struck between rewarding risk-takers and diffusing new knowledge.

- On policies to support firms, tax subsidies are increasingly being used over direct grants. However, more evaluation is needed to determine the efficiency and effectiveness of this support, as it is unclear whether the social benefits outweigh the costs. Access to secondary "high risk" capital markets, in addition to generally deep financial markets, is useful for young innovative firms. It appears that venture capital for expansion is more accessible than for seed funding. However, governments should exercise caution before providing such financing, as they are generally not best placed to assess investment projects. A lack of demand from business may also be a barrier to the development of this market. There is much interest in entrepreneurship and SME policy; however, policy rationales are not always clear. Supporting management training appears to be beneficial. Little is known about the links between government procurement and innovation and more work could usefully be done in this area.

- Support for public research has undergone numerous changes recently, such as the move to more project funding and more involvement of industry in priority setting. Evaluating these changes will be important.

- Industry-science links are a key facet of innovation and are driven mainly by the matching of university orientations to business needs. Policy action on improving and clarifying the intellectual property rights framework, supporting good governance in universities, and allowing mobility and flexibility in research employment, is recommended. 
- For regions, policies that enable adaptation and change are favoured. Linkages with local higher education institutions can help foster innovative activity and support flexibility. For clusters, the government's role is mainly as a catalyst and broker for strengthening cluster formation. A horizontal and coherent approach to policy is vital. For sectors, policies may need to be nuanced, although a robust general innovation policy framework remains central.

- Co-ordination of policy across ministerial boundaries is vital. However, good governance of this type is often held back by competing mindsets and fragmentation. Governments must work to build a common vision, share information widely, and integrate learning into policy making. Techniques for evaluation are known, but underused.

- Human capital is a vital input to the innovation process. More knowledge is needed on the measurement of this resource, especially in understanding "soft" skills such as teamwork, and on understanding how demand for human capital is changing. Social capital can augment human capital but understanding of the concept and its implications is still at an early stage. More evidence-based policy is required in the education system, particularly so that the system better adapts to change and evolving social needs.

However, evaluation of specific government support policies and their impacts on innovation is generally sparse and there is a need for more and better evidence on the costs and benefits of government support for innovation. Measurement of innovation more generally is also an area where further work is likely to yield benefits, particularly in better understanding innovation in the service sector and better capturing the increasingly international nature of innovation activities. With efforts being made across the OECD, co-ordination is essential.

There is a clear role for innovation in addressing global challenges. Taking the environment as an example, analysis shows the importance of a robust general framework for innovation, the opportunities for learning from others, the need to better understand the balance between collaboration and competition at a multi-country level, and the importance of forming a robust approach to the governance arrangements around multi-country challenges, such as climate change and water. This is essential to leverage the impact of national efforts and ensure all countries can gain from the fruits of innovation.

To conclude, many OECD countries have the framework conditions in place to boost innovation or have a range of direct instruments to foster innovation but find that innovation performance, although good in comparison to peers, has not sufficiently raised productivity and growth to improve living standards or address key global challenges. The added value of the OECD Innovation Strategy is to take our understanding of innovation and its relationship to the economy to the next level, to understand the linkages that exist between private and public investments in knowledge, innovation performance and living standards, and to address barriers to better economic and social performance. 
DSTI/DOC(2009)2

\section{Introduction}

In May 2007, OECD Ministers mandated the preparation of an OECD Innovation Strategy. The Strategy has two broad aims: first, addressing countries' needs for a more comprehensive, coherent and timely understanding of how to promote, measure and assess innovation and its underlying dynamics of change; and, second, shedding light on appropriate multi-sector and whole-of-government approaches to innovation as a driver of sustainable growth, productivity and development and as a tool to address global challenges. Work on the Strategy is to take place over 2008-09, with a synthesis report to be delivered to the Ministerial Council Meeting in 2010.

This report forms one of the outputs for Phase 1 of the project. It draws on OECD work from the last 10 years to provide a broad-brush overview of "what we know" about good policy practices for innovation. It also highlights recent changes in innovation processes and patterns, describes the increasing levels of internationalisation, and draws together early thinking on the contribution of innovation to solving global challenges related to the environment.

Following an introductory discussion on the importance of innovation for growth and wellbeing (section 2), recent trends (section 3) and the innovation systems context (section 4), the stocktaking is mapped broadly to the main pillars of the Innovation Strategy, as follows: policies: markets and governance (section 5); human capital (section 6); measurement (section 7); and global challenges (section 8).

\section{Innovation, growth and the rationale for government intervention}

Innovation has been described as the creative use of various forms of knowledge when responding to market-articulated demands and other social needs (OECD 1999a). For measurement purposes, it is defined by the Oslo Manual as "the implementation of a new or significantly improved product (good or service), or process, a new marketing method, or a new organisational method in business practices, workplace organisation or external relations" (OECD \& European Communities 2005, p. 46). The actual and perceived importance of each facet of innovation will differ across countries, in accordance with factors such as resource endowments, industrial structure, and culture. For some countries, technological innovation and research and development $(\mathrm{R} \& \mathrm{D})$ are seen as central, while for others, non-technological innovation and adoption of technological advances from other sources are more prevalent.

Innovation is inextricably linked to past and future economic performance and to societal wellbeing. Most of the rise in material standards of living since the industrial revolution has been the consequence of innovation. New or improved products and services, and new and improved ways of producing them, have for a long time been the main motor of economic growth (OECD 2006a). This trend is expected to continue. There is also the possibility of meeting global challenges with the application of innovative solutions. In recent years, policy issues have emerged in areas such as climate change, energy, health and water, that require a global perspective and for which science, technology and innovation must play a role in finding solutions.

Empirical work by the OECD supports the importance of investing in innovation for economic performance. For example:

- Multivariate growth regressions for a panel of 15-16 OECD countries over the period 1981-98 found that the level of R\&D intensity has a significant effect on growth in real per capita GDP (OECD 2003e, p. 84). Including separate variables for private- and public-performed R\&D suggested that it is business $R \& D$ that drives the positive association between total $R \& D$ intensity and output growth; however, regression analysis may not pick up complex effects and 
interactions relating to the type of research undertaken by public institutions and may underestimate the impact of public R\&D. Jaumotte \& Pain (2005c) found business sector R\&D intensity is positively related to the level of non-business R\&D intensity, consistent with the view that this sector generates basic knowledge that offers beneficial spillover effects for the private sector.

- Analysis of 16 OECD countries over the period 1980-98 showed that investment in innovation was positively associated with multifactor productivity (MFP) (Guellec \& van Pottelsberghe de la Potterie 2001). In particular, business R\&D had a positive and significant impact on MFP, indicating substantial spillovers from this investment. The impact of business R\&D increased over the period, confirming the increasing importance of technological change for economic growth, and the impact was higher in countries where R\&D intensity was higher, suggesting the presence of increasing returns. Foreign $R \& D$ also had a high and significant effect on MFP, reflecting the fact that technology spills over borders. The impact was higher for small countries and for those that had a higher R\&D intensity (showing that a country needs absorptive capacity to make the most of foreign technology). Finally, government and university-performed research had a positive and significant effect on productivity. The effect was larger in countries where universities had a higher share in public research, perhaps reflecting a more industry-oriented research approach by universities, or their more flexible project-based funding, which might allow for quicker adjustment to changing technological priorities. ${ }^{3}$

- Analysis of 16 OECD countries over the period 1980-2002 finds that stocks of domestic business $R \& D$, public $R \& D$ and foreign $R \& D$ all have positive and significant effects on productivity growth, as does the stock of human capital (Khan and Luintel, 2006). The results also show that the higher the business sector knowledge stock the greater tends to be the magnitude of international knowledge spillovers and the productivity gains from high tech imports.

Firm-level analysis also links investment in innovation to improved outcomes. Using the third Community Innovation Survey (CIS3) for 16 European countries, Jaumotte \& Pain (2005c) found that the proportion of firms engaging in innovation spending was closely correlated with the proportion of successful innovators in a country. Their results implied that a 1 percentage point increase in aggregate innovation spending was associated with an increase of 0.85 percentage points in the probability of being a successful innovator and an increase of 0.7 percentage points in the share of new products in turnover. Innovation spending included not just intramural $R \& D$, but also extramural $R \& D$, other acquisitions of knowledge (such as rights to use patents, licenses and software), investment in capital goods, expenditure on training and spending necessary for the innovation to be placed on the market (for example, marketing or design expenditures). Non-R\&D expenditures were sometimes more important than R\&D, and many of the countries with the highest proportion of successful innovators also had the highest propensity to engage in non-R\&D innovation spending - showing the importance of taking a broad view of innovation inputs. Box 5 below points to more recent cross-country analysis of the CIS surveys, using the underlying firmlevel data instead of the more aggregate indicators.

However, although the realised and potential benefits from innovation are clear, investment in innovation may be inadequate (OECD 2006a). The presence of market failures reduces incentives for

3. It is important, however, not to interpret these results as a simple "more is better" policy prescription. Guellec \& van Pottelsberghe de la Potterie highlight that there are strong interactions between various channels and sources of technology, which underline the necessity of a broad and coherent policy approach. And cross-country data for OECD show that while there is a positive relationship between R\&D intensity and measures of (for example) patenting and scientific publishing at the OECD aggregate level, the situation of individual countries can differ widely - for some countries, a high R\&D intensity has not been accompanied by a commensurate improvement in innovation outcomes (OECD 2007a). 
private investment in innovation, precluding investments from reaching socially optimal levels. In particular:

- Knowledge spillovers - when competitors and other innovators are able to use and benefit from new knowledge created by an entity, the benefits to society from investments in innovation can exceed the private returns. At the same time, because the innovator cannot appropriate all the benefits of their investment, investment will be less than socially optimal. In some cases, private investment may not occur at all, especially in areas such as basic science, where the outputs often take considerable time to emerge and do not have direct or clear commercial benefits. As noted above, empirical work has clearly identified spillovers resulting from R\&D investment.

- Information asymmetry - the outcomes of innovation efforts are highly uncertain, especially in their early stages, and can be very complex, which may make it difficult for firms to raise external funding for research and development. This is especially the case where firms are making use of intellectual assets, for which financial measurement and reporting is still underdeveloped - a lack of understanding of the contribution of intellectual assets may lead to underinvestment. The likelihood of financial constraints is especially high for (potential) new entrants into the research process, who have no history of successful research and may have limited means of internal finance (Jaumotte \& Pain 2005a). Traditional bank finance is of limited relevance to start-up or young innovative firms; instead, investors (where they are willing) look to provide risk capital through equity and quasi-equity products, where they assume high risks but may also reap high rewards (OECD 2006f). These types of products are limited in some countries.

In addition, theoretical advances in the understanding of innovation processes point to systemic failures that block the functioning of innovation systems, hinder the flow of knowledge and technology and, consequently, reduce the overall efficiency of R\&D efforts. Such systemic failures can emerge from mismatches between the different components of an innovation system, such as conflicting incentives for market and non-market institutions, or from institutional rigidities based on narrow specialisation, asymmetric information and communication gaps, and lack of networking or mobility of personnel.

These factors have been among the basis of the rationale for government intervention in science, technology and innovation. To address market failures, all OECD governments have put in place specific measures to encourage innovation (OECD 2006a). These include direct financial support and/or tax incentives, intellectual property laws and other measures to provide innovators with rights over exploitation of their work, and government owned/operated research institutions and universities. To address capital market "gaps", many countries have provided early-stage funding, or attempted to foster the development of venture capital markets. And to address systemic failures, governments look to improve the co-ordination and the degree of co-operation within the system.

More recently, governments have also been concerned to address social and environmental externalities through intervention in innovation activities. In particular, the increased level of globalisation has brought into sharper focus the positive and negative spillover effects of certain activities, which are having repercussions across national borders. The international aspect of dealing with these externalities is still not well understood and countries are seeking to find solutions.

However, an important caveat on the role of government in science, technology and innovation is that the existence of failures is not in itself a sufficient justification for policy action (OECD 2005c). In some cases, government action may be ineffective, and even if action is possible, the costs may be higher than the benefits once administrative and compliance costs (and unintended side-effects) are taken into account. Indeed, the risk of "government failure", where a lack of policy clarity, continuity and coherence deters private investment in innovation, is real. In recent years, policy attention has been dedicated to raising the 
effectiveness of policy measures so as to improve the overall efficiency of innovation systems (OECD 2006a). The key question is not how much governments spend, but what outcomes are achieved. When encouraging innovation, it is important for policy makers to know how successful their policies are in isolation and in combination with each other, and how to maximise successful innovation and spread its benefits at the lowest cost to the taxpayer.

\section{Recent trends}

The relationship between technological progress, innovation and economic growth changed in the 1990s, with innovation and technological change becoming increasingly important for economic performance (OECD 2000a). This was indicated by rising investment in innovation (with this investment becoming more market oriented, with more business R\&D), a surge in patenting driven by rapid innovation across all technology fields, and a widening of innovation activities across sectors (with services sectors increasing investment in R\&D). Investment in ICT made an important contribution to growth and labour productivity growth across the OECD (box 1), particularly where this investment was combined with other organisational assets such as new business strategies, business processes and organisational structures, and better worker skills.

\section{Box 1. The economic impact of ICT}

Information and communications technology (ICT) has become a fact of life in all OECD economies, although the level of diffusion differs across countries as a result of cost differences (including the level of tariff and non-tariff barriers) and differences in abilities of firms to absorb new technologies. Identifying the impact of ICT on economic performance has been an important strand of work for the OECD, especially since the impacts at the aggregate and sectoral level do not seem to match those at a firm level. Sectors that have invested heavily in technology, notably services sectors such as wholesale trade, financial services and business services, have not necessarily seen an upsurge in productivity growth. Yet firm-level data shows significant impacts of ICT on firm level performance, as indicated by MFP and labour productivity.

Three effects of ICT on productivity and growth can be distinguished: first, as a capital good, investment in ICT contributes to overall capital deepening and helps raise labour productivity; second, rapid technological progress in the production of ICT goods and services may contribute to faster MFP growth in the ICT-producing sector; and third, greater use of ICT in non-ICT industries such as distribution and financial services may help firms increase their efficiency and thus raise MFP. There may also be network effects, by which lower transaction costs and more rapid innovation improves the overall efficiency of the economy. Empirical evidence on these three effects shows:

- $\quad$ From 1995 to 2005, investment in ICT represented between 0.3 and 0.7 percentage points of growth in GDP in OECD countries (average annual volume change in GDP over the same period was $2.6 \%$ for the OECD);

- Countries with ICT-producing sectors have benefitted from a strong productivity performance in this sector (the ICT-producing services sector plays a smaller role but has been characterised by rapid progress); and

- The United States and Australia are almost the only OECD countries where there is evidence at the sectoral level that ICT use can strengthen labour and multifactor productivity growth. In some other countries there is evidence of a pickup in labour productivity growth, but not MFP, while in many others, there is little evidence of an improvement in either measure. At the firm level, however, individual country studies have found ICT use is associated with productivity growth. ICT use forms part of a broader range of changes that help firms enhance their performance, including complementary investments and organisational changes. Firms that combine ICT with other advanced technologies experience better results than those just using ICT.

Several factors may account for the differences at the firm and sectoral level: first, aggregation across firms and industries may disguise some of the impacts; second, earlier adoption of ICT and greater diffusion may lead to greater measured impacts in certain countries; third, measurement of this area is still difficult; fourth, countries outside the US may not yet be experiencing the spillover effects of ICT that show up in macro level impacts; and fifth, the state of competition may play a role in the size of spillovers.

Sources: OECD 2004a; OECD 2007a; OECD 2006b. 
There is now greater reliance on "intellectual assets" as the basis for innovation-oriented activity (OECD 2008e). While there is no one globally accepted definition of these assets, there is general agreement that they include R\&D, patents and trademarks, as well as human resources and capabilities, organisational competencies and "relational capital". These assets are strategic factors for value creation by firms and initial analyses for Finland, Japan, the Netherlands, the UK and the US suggest that total annual investment in intellectual assets amounts to between 7.5-11.7\% of GDP - a level similar to investment in physical assets. These estimates suggest that the factors associated with the growth of the knowledge economy are even more important than previously thought. Yet methodological challenges mean that national accounting systems and traditional corporate reporting standards still do not adequately reflect the role of these assets as a productive force, relying instead on methods that favour financial or physical capital. As noted earlier, this may lead to misallocation of resources, due to a failure to reflect the true contribution of intellectual assets to value creation.

The services sector has also become increasingly important, in terms of both output and employment in OECD countries, and business/professional and ICT-related services are playing a direct role in spurring productivity and growth (OECD 2001a). A range of factors have contributed to the increased dynamism of services in economic activity, including changing consumer demand, regulatory reform, increased competition and exposure to international developments, the growing tradability of services and higher levels of investment in and application of ICT. Services are increasingly integrated with the manufacturing, resource and agricultural sectors, and services sectors themselves are strongly integrated, suggesting that the traditional distinction between sectors is increasingly irrelevant. Many barriers to innovation in services are the same as those faced in the manufacturing sector.

At the same time, it is difficult to draw an accurate picture of the amount of innovation in services - it is frequently non-technical in nature, depending more on acquired technology, organisational change and human capital, and involves small and incremental changes in processes and procedures that do not require significant amounts of R\&D (OECD 2001a). Services innovation is more linked to consumer demand and less linked to scientific advance than innovation in other sectors. Improving definitions and statistics for services would be of value, ensuring that the variety of market structures and drivers of performance in services are taken into account. Some advances have been made in the understanding of non-technological innovation - recent analysis of firm-level data confirms that non-technological innovation is an important component of innovative activity in many countries (OECD 2008s : Chapter 5). The share of firms having introduced a marketing or organisational innovation ranges from around $60 \%$ of all firms in Luxembourg, Denmark, Germany and Austria, to around 30\% in Norway and the Netherlands. Interestingly, the shares are similar for both services and manufacturing industries.

\section{The innovation process}

Changes have also been taking place in the innovation process itself (OECD 2000a). For example, there has been a shortening of technology cycles in some sectors, as firms seek to obtain concrete results from their R\&D expenditures and face market pressures to develop products more rapidly. Research activities are being more closely tied to business strategies. And links to basic scientific research rose in importance for a number of countries, as many of the technologies transforming society, such as the Internet, were sourced from basic research, and scientific institutions played a role in establishing research and innovation networks to underpin technological diffusion and innovation.

The (partly market-driven) convergence of technologies, particularly nanotechnology, biotechnology and ICT, also raises new challenges to established methods of supporting R\&D to promote innovation. Indeed, scientific and technological advances occur at the interface between different disciplines, challenging the ways governments fund such public research or foster pre-competitive commercialisation. 


\section{DSTI/DOC(2009)2}

But perhaps the greatest trend affecting innovation processes is globalisation - the expanded flows of information, technology, capital, goods and services, and people throughout the world. Trade and foreign direct investment (FDI) have grown at a faster pace than GDP since the end of the second World War, stimulated by the growing openness of the trade system, liberalisation of capital movements, the international activities of multinational enterprises (MNEs) and the growing movement of people across borders. Trade and investment affect innovation through various channels - as sources of technology, through competition effects, and through scale economies (OECD, 2008x forthcoming). These developments have been driven in part by on-going domestic and international policy reforms. The multilateral trading system plays an important role in co-ordinating and promoting such policies, and has also contributed to enhanced integration of emerging economies in global markets (OECD 2006g). Successful conclusion of the Doha Development Agenda would contribute further by lowering trade barriers for both goods and services, thereby providing access to more technology and promoting competition and innovation (OECD, 2008x forthcoming).

Globalisation is seen as an overarching "megatrend" that is likely to shape the world in the coming years. It is typically regarded as a force that will sustain world economic growth, raise world living standards, and substantially deepen global interdependence. But at the same time, it creates economic, social and environmental challenges. The greatest benefits of globalisation may accrue to those countries that can best access and adopt new technologies.

There are several aspects of globalisation and internationalisation that have been analysed by the OECD in recent years, discussed below. One general theme arising from the work is the "organic" nature of much of this activity. For example, in a study of business R\&D, many countries stressed that many forms of international S\&T co-operation were the result of individual contacts and initiatives between researchers, companies and research organisations, without any backing government strategy (OECD 2008t). A second theme is the increasing "mismatch" between policy that has a domestic focus and economic activity that has an international focus. These themes will have important implications for policy work in the Innovation Strategy.

\section{The internationalisation of $R \& D$}

Until recently, the technological capabilities of firms have been less globalised than other activities such as marketing and production. Now, firms are increasingly off-shoring R\&D activities to other countries $^{4}$ (OECD 2008t). As well as aiding the adaptation of products and processes to local conditions, off-shoring also enables firms to source technology internationally and tap into worldwide centres of knowledge. Most R\&D investments still go to OECD countries; however, China and India, among other emerging countries, are increasingly considered as attractive locations for R\&D (although, with intellectual property (IP) enforcement concerns, they may only attract certain types of $R \& D$ ). The increasing volume of R\&D investments abroad is matched by the increasing importance of foreign affiliates in patenting statistics show a rise in both domestic ownership of patents abroad and foreign ownership of domestic patents.

Increased off-shoring has raised concerns, especially for small countries, about a possible erosion of home-based R\&D and reduced absorption capacity. Turning this process into a global win-win situation will require a stronger policy focus on: encouraging "brain circulation" and knowledge exchange so as to better access foreign know-how; embedding FDI in R\&D into the local environment and fostering spillovers; enhancing the exploitation of home-based knowledge in developing countries; and strengthening the relevance of international collaboration by focusing on thematic priorities in fields with

4. The same is true of environmental $\mathrm{R} \& \mathrm{D}$, although what is being outsourced internationally is mostly "development", with "basic research" remaining at headquarters. See OECD (2008k). 
global importance (OECD 2008t). Furthermore, countries need to recognise that in a world where there is international division of labour, not all locations will specialise or be involved in the same activities (OECD 2005c). Countries need to play to their strengths rather than necessarily "follow the herd".

\section{Open innovation}

As companies rely more on intellectual assets, they have also become more open in their innovation strategies (OECD 2008q). Firms have become more active in licensing and selling the results of their own innovation to third parties, and they are basing more of their own innovation on knowledge assets that lie beyond firm boundaries. This is being driven by the ongoing process of globalisation, with more intense competition and pressure to innovate quickly. Large companies, in particular, are increasingly adopting "eco-systems of innovation" across countries, where R\&D facilities are placed abroad to be close to markets and to sources of engineers and researchers.

The approach to openness differs across firms, depending on the importance of the technology, the strategy of the firm and the characteristics of the industry. Case studies show that companies focus on searching for specific technologies or products, rather than seeking to collaborate with specific companies, and are using open innovation as a strategic tool to explore new growth opportunities at lower risk. Collaboration with suppliers and customers is the most common mode.

For firms, a key issue with open innovation is the effective management of IP in an environment of increased interaction with outside parties - companies perceive the main barrier to the internationalisation of $R \& D$ to be the risk of leakages of information and proprietary knowledge. For governments, robust framework conditions and a well connected innovation system that enables knowledge flows and personnel mobility are important policy implications arising from open innovation. More challenging, however, is the question of capturing national benefits from the spillovers of eco-systems of innovative firms that span national borders. Cost-sharing and reciprocity agreements, as well as joint development and public/private partnerships, could help. The potential national benefits must be communicated and demonstrated to public stakeholders.

\section{Internationalisation of science}

While the production of scientific publications is still highly concentrated in a few countries (in-line with $R \& D$ expenditures), the increasing importance of emerging countries is reflected in their (absolute) number of S\&E publications (OECD 2008t). China has become a top-10 player and the scientific output of Latin America has tripled since 1993. In addition, indicators of international co-authorship show increasing collaboration across borders in science. Co-authorship is an important tool for mutual interaction among researchers with different knowledge backgrounds in order to diversity their sources of knowledge. Data on patent activity shows a surge in innovative activity in Asia, following the growing expenditures on R\&D in these countries (although when normalised using total population, the importance of emerging countries is much smaller). There is also a growing share of patents involving international co-invention.

\section{Mobility of human resources}

Alongside sustained internationalisation in $\mathrm{R} \& \mathrm{D}$, mobility of human resources in science and technology (HRST) has become a central aspect of globalisation (OECD 2008r). Mobility of HRST is important, due to its contribution to the production and transmission of codified and tacit knowledge, the latter of which is more effectively shared when people have a common social context and some spatial closeness. Both sending and receiving countries can benefit from HRST mobility, due to the knowledge flows and linkages established by mobile workers. Data shows that most OECD countries have net inflows of highly skilled people, including increasing flows of students. Labour markets are clearly 
internationalising, and some evidence points to strong immigrant contributions to patent activity and technology firm creation in their country of residence. OECD countries offer a variety of policies focused on assisting and encouraging mobility, although the scale of these policies differs widely across countries. Jean et al. (2007) note that migration policies, by affecting the types of migrants that enter the country, influence the labour market impact of immigration and also future integration outcomes (since integration depends strongly on migrant characteristics). However, there are limits to this impact, as non-discretionary immigration flows are substantial (e.g. family reunification, humanitarian and illegal), and selective immigration policies are difficult to design and manage, with their outcomes not always meeting expectations.

\section{ICT as a driver of change}

In many cases, ICT, particularly the emergences of the Internet, the World Wide Web, the browser and electronic commerce, facilitated these changes in innovation processes by significantly reducing the costs of international co-operation, networking and knowledge diffusion. Technological advances in ICT have helped make it possible to slice up the value chain and to fragment the production of goods and services across countries (OECD 2008t). They have also enlarged the number of goods and services that can be traded internationally. At a broader level, the growing phenomena of "user-created content" on the internet (defined as content made publicly available on the internet, which reflects some creative effort and which is created outside of professional routines and practices) is contributing to new business models, new innovations, increased participation in knowledge production, dissemination and use, and increased diversity (OECD 2007k). The 1997 Information Technology Agreement (ITA) in the WTO to cut tariffs on information technology products has contributed to diffusion of ICT through the lowering of price differentials between countries; further expansion of the ITA, both in terms of geographical coverage and product coverage, could contribute to greater diffusion of ICT and to greater innovation (OECD, 2008g).

\section{The innovation systems context}

The trends described in the discussion above clearly set out some policy challenges for governments. Faced with market and systemic failures and a fast changing environment, what is the best policy approach to innovation?

To provide a solid footing for policy discussions, it is useful to first think about how innovation "works". Recent thinking has focused on innovation as a systemic phenomenon, departing radically from earlier linear concepts of innovation as the end-stage of a process driven mainly by scientific advances in basic research (OECD 2001c). The term "national innovation system" (NIS) is used to represent the set of institutions, both market and non-market, that influence the direction and speed of innovation and technology diffusion in a country and the knowledge flows that move between these institutions (OECD 1999a). Using the NIS concept highlights interactions and interfaces between various actors and the workings of the system as a whole, rather than the performance of its individual components.

Figure 1 shows the actors and linkages in innovation systems. Firms, research bodies, the science system and other supporting institutions are the main actors influencing knowledge generation, diffusion and use, and together they constitute a NIS. Innovation systems, with these actors as members, also exist at other levels - as global networks, regional systems or local clusters of industries. The conditions faced by actors, with respect to factor markets, product markets, education systems, communications infrastructures, and macroeconomic and regulatory settings, strongly shape a country's innovation capacity. 
Figure 1. Actors and linkages in the innovation system

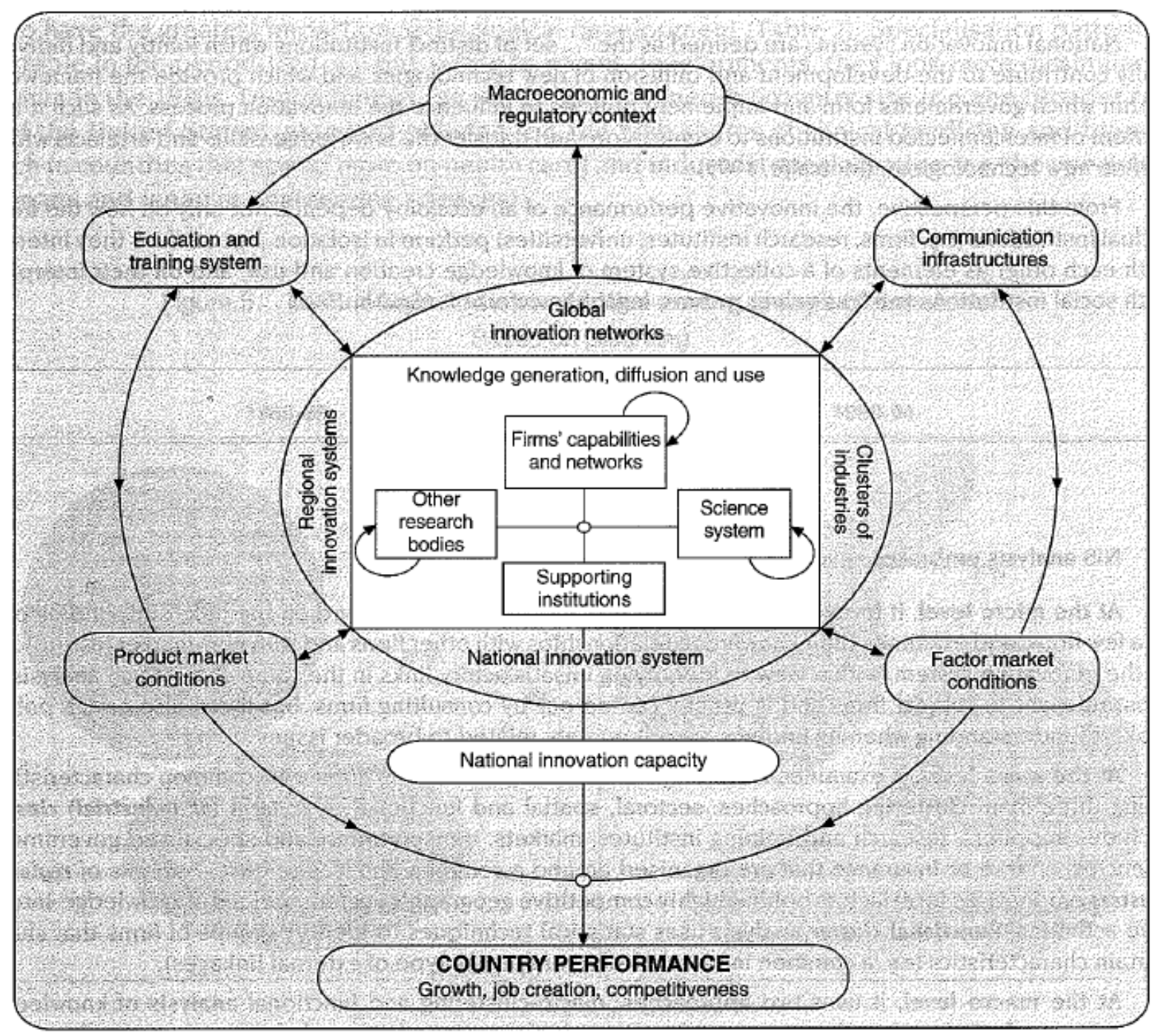

Source: OECD 1999a, p. 23

The structure of countries' national innovation systems helps explain international differences in innovation performance, with different weights and relative focus of public and private sectors in funding and performing $\mathrm{R} \& \mathrm{D}$, different objectives and instruments of government support, different roles of government ministries, and different scientific, technological and industrial specialisations all contributing to different institutional arrangements and outcomes (OECD 1999a). In turn, this reduces the scope for "one-size-fits-all" policy prescriptions. For example, while common innovation modes ${ }^{5}$ can be identified across countries, there is no "same" mode that is consistently linked to labour productivity across countries (OECD 2008s: Chapter 5). Different modes are significantly related to the level of productivity in each

5. One way of classifying firms is by "innovation modes", using the criteria of innovation novelty and location of innovation development (in-house or external). For example, the mode of "new to market international innovator", seen to varying extents in most countries, is one where firms have introduced a product or process innovation that is new to international markets and that has been developed in-house. 
country, suggesting there are major national differences in comparative and competitive advantages, implying potentially different patterns of response to similar policy instruments.

Nevertheless, there are some policy approaches that can be recommended more broadly. Much work has been done to identify the policies, institutions and framework conditions that can provide the most effective means of supporting innovation. Empirical analysis shows that there is a clear role for framework conditions, framework policies and specific science policies in supporting innovation, both independently and in interaction with each other (Jaumotte \& Pain 2005b). Policies that raise the absorptive capacity of the economy (the capacity to understand and make use of new knowledge) have dual benefits, not only helping to stimulate new innovative activities but also helping to maximise the benefits to be gained from the existing stock of knowledge. And policies and conditions that help make knowledge more accessible can be very effective - particularly in accessing the foreign knowledge stock and sharing knowledge between the business and non-business sectors.

The next section outlines the role of government in setting appropriate framework policies, supporting firms, providing public research, and facilitating linkages between industry and science. The regional and sectoral dimension of policy is also considered, as are broader governance issues. Human capital is discussed in section 6 .

In looking at these policies for innovation, there are several overarching ideas that are important to consider:

- First, policies need not be ones that are the most likely to favour the development of new innovative ideas - it is at least as important to ask whether optimal use is being made of the existing stock of knowledge as it is to ask how that stock can be expanded (Jaumotte \& Pain 2005b). Furthermore, an implicit assumption made in much of the innovation literature is that more innovation-related activity is always better than less. In principle this need not be the case, especially if there is unnecessary duplication of research efforts. Equally, research outputs are not all of equal value. What is important is to obtain the maximum benefits from the resources being used in the research process and to address any market or policy failures that may be holding back the level of research and innovation that takes place.

- Second, account must be taken of policy tradeoffs and policy interactions - some policies that offer benefits may also have costs that could adversely affect innovation, and others have tradeoffs when considered in combination.

- Third, there is a need for patience when considering innovation policies. Many of the concepts involved and many of the objectives sought are difficult to measure, and the time taken for the level of innovation activities to change substantially can be lengthy.

- Fourth, the mix of innovation policies in any given country will depend to some extent on country specific factors, such that one size does not fit all (OECD 2005c). The particular strengths and weaknesses of a country, and the opportunities and threats it faces, as well as how these are perceived, are a major factor. Countries also update their policy mix at different speeds, so some differences will be observed even if the goal is the same. Differing political orientations and differing objectives, as well as different policy processes, will play a role. Finally, the economic and industrial inheritance of a country will shape policy approaches. In this vein, the OECD's 2006 Going for Growth work (2006a) provided country-specific policy recommendations to strengthen innovation performance, based on country indicators and analysis. 


\section{Markets and governance}

\subsection{Framework conditions}

Innovation effort and performance are influenced by the broad economic environment. As such, the conditions governments put in place around areas such as markets and competition, macro-economic settings, trade and openness, the regulatory and legal framework, and the financial system, are of vital importance. Education is another key condition - this is discussed separately in section 6 on human capital.

\section{Macroeconomic policies}

Stable macroeconomic policies have a critical role to play in enabling economic changes that are conducive to higher growth of GDP per capita and productivity (OECD 2001b). Fiscal discipline, low inflation rates and a reduction in the variability of inflation help to reduce uncertainty and enhance the efficiency of the price mechanism in allocating resources. This results in an improved environment for decision making and unleashes resources for private investment. Looking at some empirical evidence:

- Regression analysis of 21 OECD countries over the period 1971-1998 found that the size of government, as indicated by the overall tax burden, has a negative impact on output per capita (OECD 2003e, p. 83). This provides support for the idea that tax pressure influences the efficiency of resource allocation across different investment projects.

- For the same group of countries, the variability of inflation was an important negative influence on output per capita, supporting the hypothesis that uncertainty about price developments affects growth via its impact on economic efficiency (OECD 2003e, p. 82). The impact of the level of inflation was less clear-cut; however, the lack of a robust relationship between inflation levels and GDP per capita may have been due to the low inflation environment observed in many OECD countries.

- Jaumotte \& Pain (2005b) found, all else being equal, ensuring stable macroeconomic conditions and low real interest rates helps to encourage the growth of innovation activity.

\section{Openness}

One of the main drivers behind promoting technological innovation and productivity gains has been the expansion of markets worldwide (OECD 2001b). Progress in reducing tariff barriers, dismantling nontariff barriers and liberalising capital markets has opened up opportunities in trade and international investment. Openness increases the size of markets available to innovators and consumers, while facilitating the spread of knowledge, technologies and new business practices. Analysis suggests that an increase of 10 percentage points in trade exposure (a weighted average of export intensity and import penetration), for example, could increase steady-state output per capita by as much as 4\% (OECD 2003e, p. 89). Another aspect of openness that is equally important is about culture and a readiness for change recognising that knowledge and ideas are important for economic growth and being willing to transfer and share these among economic agents.

Innovation performance is particularly related to the degree of openness of the economy to knowledge and ideas generated abroad. Apart from the effects arising from stronger competitive pressures, greater openness can lead to increased knowledge absorption via a number of channels, including imports of goods and services, investment flows, mobility of workers, and collaborative research and innovation (OECD 2006a). A low level of restrictions on foreign direct investment is a helpful means of improving crossborder knowledge transfers (Jaumotte \& Pain 2005b). Other work has also shown that reduction of trade 
and foreign investment barriers in services would help strengthen competition and promote the diffusion of innovative ideas and concepts across countries (OECD 2001a).

\section{Competition}

Policies that affect the intensity of competition have an impact on innovation efforts. But neither economic theories nor empirical studies have been able to determine which degree of market concentration/market contestability faced by which types of firms produces the most innovation (OECD 2008c). On the one hand, strong competition encourages companies to innovate to stay ahead of competitors. On the other hand, a degree of market power may stimulate innovation activity by facilitating cost recovery of related expenses. In the middle ground, some research has found that many industries exhibit an inverted U-shape correlation between competition and innovation, suggesting moderate levels of competition are most highly correlated with more innovation. However, this has not been definitively confirmed. Furthermore, the extent of this relationship is also influenced by the industrial sector and stage of technological development (Figure 2). A balance has thus to be struck - the right policy environment for innovative activity is one that gives adequate rewards to innovation, while ensuring competitive pressures that encourage firms to create, implement and diffuse innovations (OECD 2006a). The OECD (2003e, p. 99) has argued that, for any given level of protection of intellectual property rights, greater competition is likely to lead to stronger productivity performance.

\section{Figure 2. Innovation intensity and technological development}

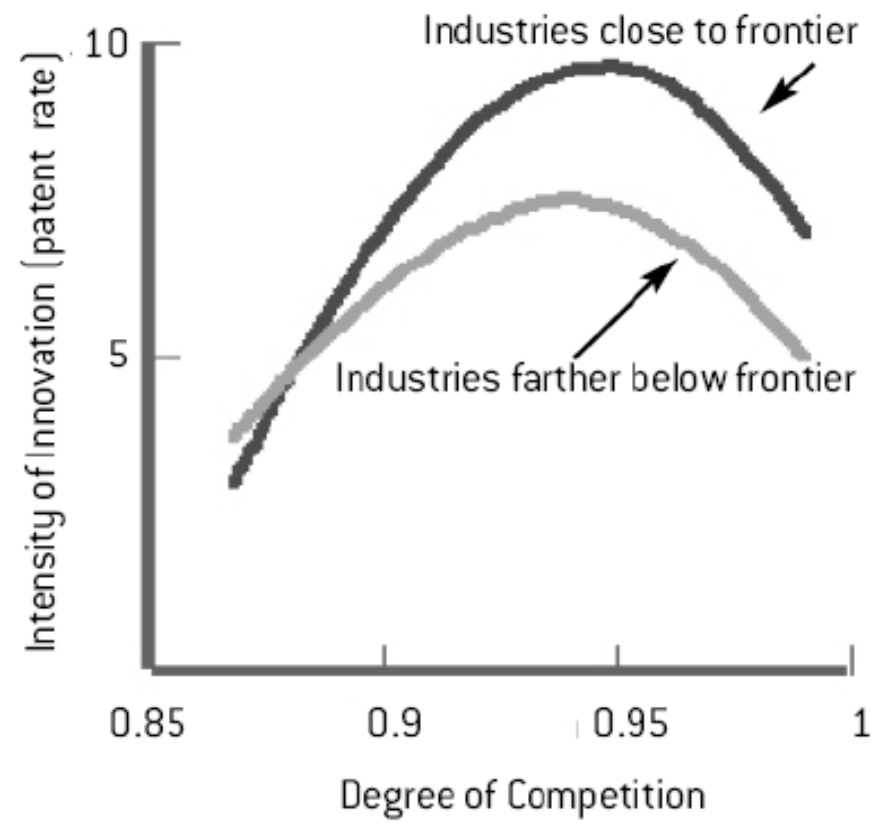

Source: Aghion et al. (2005)

One particular policy area where decisions must be made about the level of competition is mergers. With the uncertainty over the exact relationship between competition and innovation, and the difficulties in assessing levels of competition in the market (considerations include not just concentration but also geographic factors), it is not surprising that case-specific inquiries are required to determine whether a merger will promote or prevent innovation (OECD 2008c). A merger could lead to efficiencies in R\&D, but reduced rivalry and greater market power could slow the post-merger rate of technological change. In some cases, firms seeking to merge claim dynamic efficiencies that could facilitate or encourage innovation; however, these are extremely hard to assess and measure and quantitative assessments do not 
appear to be feasible at present (OECD 2007n). Overall, the traditional merger review framework is applicable to innovation intensive markets, although some customisation in approach is needed regards: defining markets and assigning market shares; assessing the significance of changes in market structure; giving proper weight to benefits reaped by consumers from innovation; assessing the ability of merging parties to exclude or restrict competitors; and designing appropriate remedies (OECD 2003f).

Another important policy area is anti-trust. Most agree that competition law should not be used as "a bludgeon" against intellectual property rights (IPRs), since this could stifle innovation (OECD 2008c). Compulsory licensing as an anti-trust remedy should be approached with caution and ordered only after a careful review of the facts and in the face of a clear anti-competitive use of substantial market power. In new areas such as biotechnology, the rapid growth and complexity of the industry also calls for caution by competition authorities, since action could have the unintended effect of discouraging innovation (OECD 2005d). For example, while collaboration between patent holders may present anti-competitive characteristics, it may also encourage pro-competitive behaviour, such as increasing access to goods, technologies, information and services. Indeed, a number of competition authorities are becoming more open to the use of collaborative mechanisms (OECD 2007p and OECD 2005d). ${ }^{6}$

\section{The regulatory environment}

Regulatory regimes can significantly influence the size, dynamism and functioning of innovative firms. While regulations aim to correct market failures and distortions in order to promote better market functioning, there is a risk that poor regulatory design will place excessive regulatory burdens on business. Firms particularly point to regulations in finance and access to capital, technology, and human resources, as key areas that affect their performance. Issues pertaining to particular policy areas are picked up as appropriate throughout this paper.

Many countries have undertaken regulatory reform programmes to improve the quality of regulation. For example, in relation to small and medium-sized enterprises (SMEs), many countries have attempted to address concerns about paperwork and administrative burdens through the introduction of one-stop shops and better electronic networks for the provision of information (OECD 1999b). Improving the regulatory environment for SMEs involves a number of considerations (which are also applicable to firms in general):

- Regulatory policy should be forward-looking and part of a broader strategy to foster a large and healthy community of firms;

- Regulations should ensure an economic structure within which firms have a fair opportunity to compete;

- Attention should be given to the cumulative effect of regulations; and

- Regulations that affect flexibility for entrepreneurial activities should be carefully considered.

Ensuring regulation is appropriate is important - for example, work on ICTs found an appropriate regulatory and legal environment, particularly in the areas of privacy, security and consumer protection, is required to boost the diffusion of ICT and the use of e-commerce (OECD 2001b). The key is to underpin confidence in the use of these technologies. (Promoting positive attitudes to technology, for example by

6. For example, the European Commission has issued guidelines to assess the competitive effects of patent pools, which focus on the complementarity of the patents in the pool. In the United States, while there are no explicit guidelines, reviews of patent pools by the Department of Justice point to several criteria and limitations that must be taken into account when setting up pools, including that the pool must be essential (i.e., the patents are complements and none has a substitute outside the pool) and that each patent holder must be allowed to license its technology outside the pool. 
using ICT applications in government-public transactions [such as collecting taxes, or procuring goods and services online], can also assist.) Multilateral processes, such as the World Trade Organisation's (WTO) General Agreement on Trade in Services (GATS), may also contribute to more effective and well-balanced regulation in the service area (OECD 2001a).

Considering the national regulatory environment also highlights a distinct positive connection between competition and innovation (OECD 2008c). Empirical studies by the OECD have found a negative correlation across national economies between the level of anti-competitive product market regulation and innovation. Other work, looking at 18 countries and 18 manufacturing industries, also found an unambiguous negative association between $R \& D$ intensity and indicators of non-tariff barriers and inward-oriented economic regulation (Bassanini \& Ernst 2002). Of the many policy levers studied, reducing anti-competitive regulation was found to be the second most powerful incentive to raise the level of business R\&D spending (see Jaumotte \& Pain 2005b).

Entrepreneurship can be stifled by excessive or unnecessarily complicated regulations related to business registration, administrative processes and bankruptcy/insolvency (OECD 2001b). Reform of regulatory structures to promote competition and innovation and to reduce barriers and administrative rules for new entrants and start-ups can yield considerable benefits. The OECD's new "Competition Assessment Toolkit" (see OECD 2007q and OECD 2008d) can assist governments in reducing unnecessary restrictions on competition. The kit provides a general methodology for identifying unnecessary restraints and developing alternative, less restrictive policies that still achieve government objectives.

\section{Financial systems}

For start-up or young innovative firms, a key hurdle is often access to finance. A well developed financial system helps foster investment in innovation by increasing the availability and reducing the cost of finance from sources that are external to the firm. Market-based finance also better facilitates the process of creative destruction.

As pointers for policy, general financial development, and deep stock markets in particular, are strongly linked to cross-country differences in R\&D and patenting activities over time (OECD 2006a). The market for high-risk capital, in particular venture capital (VC) and less formal sources of finance such as business angel funds, play a key role in enabling entrepreneurial individuals to turn new ideas into new products. For new firms, access to secondary financial markets with easier rules of access, and to VC, has enabled the commercial implementation of major innovative ideas and technologies and has facilitated access to experienced management and strategic advice (OECD 2000a). It is pertinent to note that, in some cases, government policies can worsen access to such sources of finance - for instance, in some countries, rules that aim to protect certain classes of investors against overexposure act to prevent or discourage pension funds, insurance companies and other institutions from VC investment (OECD 2001b). Taxation can also act as a barrier to the development of risk capital and VC.

Continuing to improve financial reporting would also assist enterprises engaged in innovative activity (OECD 2008e). In particular, ensuring that information on intellectual assets is consistent and comparable over time and over companies would help investors to better assess future earnings and the risks associated with different investment opportunities. This should contribute to making financial markets more efficient and improve the ability of firms to secure funding at a lower cost of capital. Governments can assist in the efforts to promote identification and dissemination of best practices in reporting, including in the nationallevel accounts. 
DSTI/DOC(2009)2

\section{Intellectual property rights}

Establishing intellectual property rights allows innovators to more effectively appropriate the results of their intellectual and financial investments, thus creating more incentive to take a risk and invest in innovation activities. It also facilitates the transfer and dissemination of technology by allowing others to gain the rights to use the technology from the innovator. However, enhanced protection of IPRs has costs as well as benefits, due to a potential reduction in the use of inventions during the lifetime of protection, a potential duplication of research efforts and, with much innovation being cumulative, the potential for stifling subsequent development of product and process enhancements (Jaumotte \& Pain 2005b). Intellectual property protection also interacts with product market competition - strong IPRs can offset the potentially beneficial effects of stronger competition on innovation if they prevent the rapid diffusion of knowledge from firms at the technological frontier to potential rivals. The resulting technological gap can reduce the returns from innovative activities for competitors and reduce the incentive for incumbents to innovate further to maintain market share.

A framework of domestic, regional and international institutions governs the administration of intellectual property rights. One particularly important development in recent years was the advent of the WTO's Agreement on Trade-Related Aspects of Intellectual Property Rights (TRIPS), which came into effect in 1995. Building on the existing framework of agreements administered by the World Intellectual Property Organisation, the TRIPS Agreement represents an international commitment to establish enhanced and global minimum standards for the protection of intellectual property. This trade policy development provided impetus for institutional reforms and a general strengthening of intellectual property rights around the world, which in turn may have an influence on the volume and composition of international trade and investment, including with respect to technology transfer (Park and Lippoldt, 2008).

What is the ideal level of IPR protection for innovation? Some OECD work argues that strong IPR and strong competition (as measured by product market regulation) is the most supportive policy package for innovation, although as mentioned above, at very high levels IPR can offset the benefits of competition. At industry level, studies show that the effects of patents on innovation vary substantially from industry to industry and it is not clear that innovation is always favoured by a stronger patent system or one in which patents are easy to obtain (OECD 2008c). Patents seem to be important in motivating firms to invest in R\&D in only a handful of industries, such as the chemical and pharmaceutical industries. Surveys have also found that patents are important in the plastics and medical instruments sectors, and some machinery sectors. Elsewhere, firms rely more on secrecy, time to market and customer sales and service to protect the returns on their inventions.

Firm level analysis changes the picture a little. Recent analysis of the incentive effects of IPRs, based on firm level data from 8 countries, suggests that the premium offered by patent protection has a positive effect on firms' innovation efforts, especially R\&D efforts (as represented by expenditure) (OECD 2008s : Chapter 5). This incentive effect can explain between 1.5 and 12 percentage points of the cross country differences in the shares of firms that are involved in innovating activities. The size of the effect varies widely across countries - patents were particularly important for Denmark and Belgium, and less important in Finland, Germany and Norway. The analysis also found that IPR protection is more frequent among product innovators than process innovators. Interestingly, the analysis suggested that differences in patenting performances across countries might be due to differences in the number of innovative firms, rather than different propensities to patent.

Other work also suggests that the degree of protection for IP is positively correlated with R\&D intensity, but notes that the strength of IP rights may in fact be partially endogenous to the level of innovation (Jaumotte \& Pain 2005a). The impact of enhanced patent protection is greater in those countries 
with weaker initial levels of protection, and increased patent claims in such countries often came from foreign residents, suggesting better access to foreign ideas (at least to some threshold point).

In practice, in almost all countries, the general tendency of IP policy has been to offer ever greater protection for the rights of IP holders, particularly with respect to patents (Jaumotte \& Pain 2005b). Some commentators take the position that patenting standards have been lowered over the last 10-20 years and that too many patents are being issued (OECD 2008c). The case for further strengthening of IPRs for patent holders in OECD countries appears weak, especially in those that already have comparatively strong patent protection (Jaumotte \& Pain 2005b). A further consideration in thinking about appropriate IP systems is that other reward mechanisms are available, as evidenced by some innovative activity that takes place without any recourse to formal registration of property rights - this means an IP system is unlikely to be optimally suited to all types of innovative activities. Some analysis suggests that the system could benefit from greater interaction between competition authorities and patent agencies, since competition authorities have a core competency in examining the effects of restraints, and could advise on the impact of current laws and intended reforms (OECD 2008c).

Against this trend to protection, however, there has been some discussion about the use of collaborative mechanisms to make better use of intellectual property within the life sciences, particularly the biotechnology field (OECD 2007p). Collaborative mechanisms, such as patent pools, are aimed at stimulating innovation and access to IP, while ensuring a return on investment, and have been used successfully in other industries to promote technology transfer. The main incentive for a firm to participate in a patent pool is to access other basic "building block" patents necessary to develop new products. The pooling mechanism also reduces transaction costs and spreads the risks associated with R\&D, and may foster information exchange beyond that contained in the patent. While patent pools raise market power issues (see also OECD 2005d), competition authorities have now put in place policies and guidelines for their operation - indeed, there is some convergence in the approaches across countries. Analysis and experimentation with patent pools and other forms of collaboration, such as consortia, is continuing.

There is also increasing analysis on the topic of knowledge markets - where mechanisms are established to enable and support the mobilisation, sharing and exchange of information and knowledge, including but not limited to IP (OECD 2008g). These markets aim to reflect the true value of innovation and knowledge. In health, for example, underdeveloped or underutilised information (such as information associated with failed and abandoned projects) could be shared and used to avoid research duplication and wastage or to reorient projects towards achievable goals. An OECD workshop on knowledge markets, looking at what knowledge can be shared, what infrastructures are required and what policies might be necessary, is scheduled for autumn 2008.

The effectiveness of current IPR protection in the services industry is unclear (OECD 2001a). Patents are little used by services industries because they are designed primarily for technical products. Services industries are more likely to use trademarks, copyright, protection of trade secrets or simply a first-tomarket strategy. It is not clear whether current regimes constrain or facilitate innovation in services.

\section{Labour markets and workplaces}

The influence of labour market regulation on the incentives to innovate varies according to the type of industry and wage bargaining systems in place (Bassanini \& Ernst 2002; OECD 2006a). For the bulk of industries, not least in services, the full exploitation of cost-reducing innovations will often require staff reduction or changes in the skill-mix of the workplace. Stringent job protection raises the cost of such changes, reducing the profitability of new innovations. However, in countries with a co-ordinated system of industrial relations there seems to be a negative association between labour market flexibility and R\&D intensity in industries with a more cumulative knowledge base (Bassanini \& Ernst 2002). Nevertheless, 
more broadly, in periods of technological change, well functioning labour markets are crucial. Institutions must ensure that affected workers are given the support and the incentives they need to find new jobs and possibly to retrain. Institutions and regulations that hinder the mobility of workers and prevent the rapid and efficient reallocation of labour resources must be reviewed (OECD 2001b).

In maximising the impact of innovation, "high performance work practices" based on innovation, high skills, organisational flexibility and trust, are generally linked to better outcomes - higher labour productivity, higher sales, positive employment performance and lower staff turnover, as well as stronger and more productive linkages with customers and suppliers (OECD 1998a). The key features of high performance workplaces are the organisation of work to effectively exploit technology and the premium placed on building and using intangible assets, most importantly technology and human resources, with the goal of using assets more effectively.

With this in mind, countries need to ensure that firms are able to experiment with and adopt new forms of organisation that better meet their needs (OECD 1998a). Policy suggestions include:

- encouraging innovation: providing straightforward business regulations, liberal product and labour market regulation and access to finance;

- accelerating diffusion of organisational innovations: providing information on the benefits and costs of adopting organisational innovations;

- $\quad$ raising skills: providing the broad infrastructure for compulsory and basic education, improving the quality of education, encouraging more people to obtain post-secondary degrees, and improving training and retraining of workers (the "lifelong learning" concept). Related to this is helping to improve understanding, appreciation and reporting of intangibles (including human capital) by enterprises, while eliminating policy conditions which unnecessarily discriminate against investment in such assets and working towards the long-term goal of indicators of intangible assets and a robust reporting structure; and

- encouraging labour-related flexibility: expanding information on the benefits of performancerelated compensation, enabling flexible working hours and greater variability in working time, supporting skill formation in part-time employment, and enabling the development of a competitive agency-work industry.

Social security regulations are an area of labour market regulation that can pose particular burdens on firms, especially SMEs. Rules pertaining to retirement, pensions and health benefits tend to have higher unit costs for smaller firms, and also tend to reduce labour mobility, making it more difficult for SMEs to recruit (OECD 1999b). In addition, over a certain threshold of employees, a greater number of regulations must be complied with in most countries, which may potentially result in black labour markets with working conditions below minimum regulatory requirements. Although necessary to protect employees, labour-related regulations which are overly rigid or inflexible can suffocate firms.

$\operatorname{Tax}$

The structure and levels of taxation in an economy have a direct bearing on innovative activity (OECD 2008b and OECD 2008j). Corporate taxes can distort factor prices, resulting in a substitution between capital and labour, resulting in an inefficient factor input combination that lowers total factor productivity (TFP). Reducing corporate tax rates and removing special tax relief can enhance investment by improving its quality (by reducing tax-induced distortions in the choice of assets) and increasing the return on innovative activities. Empirical evidence shows that corporate taxes have a negative effect on innovation incentives for "catch-up" firms, who are working towards achieving best practice. Providing greater certainty and predictability in the application of corporate income tax, and reducing complexity and 
administrative costs, may also lead to higher investment. Larger and older firms' investment is more sensitive to changes in corporate taxation than other firms, suggesting that favourable tax treatment of investment in small firms may be ineffective in raising overall investment. To the extent that corporate tax reduces FDI and the presence of foreign MNEs, it can hinder technology transfers and knowledge spillovers to domestic firms.

On personal income taxation, flattening the tax schedule could be beneficial for entrepreneurship (by influencing the risk decisions taken by individuals) and for GDP per capita (OECD 2008b and OECD 2008j). Progressivity, while playing a role in achieving a more equal distribution of income, distorts individual decisions to supply labour and invest in human capital, and growth regressions point to a sizeable adverse effect of progressive tax schedules on GDP per capita (controlling for human capital) reflecting the responsiveness of labour supply and lower entrepreneurship and risk-taking. There is a negative relationship between top marginal personal income tax rates and the long-run level of TFP. To the extent that labour taxes affect the relative price of capital and labour, capital intensity is also affected, potentially leading to combinations of capital and labour inputs that differ from the most effective technology available and lowering the efficiency in the use of inputs. Empirical evidence shows employer and employee social security contributions negatively influence TFP. In addition, analysis shows that the negative impact of top marginal tax rates on TFP is stronger in countries with a high level of product market regulation, suggesting complementarities between taxation and product market policies. Finally, high top marginal tax rates will increase the average tax rates paid by high skilled and high income earners, possibly encouraging their migration to countries with lower rates, and possibly resulting in lower innovative activity and productivity.

\subsection{Firm support}

In addition to setting broad framework policies that are conducive to innovation, governments may also wish to push innovation more directly through various forms of support to firms. The business sector is the engine of innovation in most national innovations systems, being the major source of financing of domestic R\&D in the OECD and also the major performer of R\&D (see table 1). Governments are increasingly attempting to harness the innovative capabilities of firms to help solve challenging problems, including those environmental and social externalities to which firms themselves contribute.

Table 1. R\&D performance and financing

\begin{tabular}{|l|c|c|c|c|}
\hline & \multicolumn{2}{|c|}{ \% of GERD performed } & \multicolumn{2}{c|}{ \% of GERD financed } \\
\hline & $\mathbf{2 0 0 5}$ & $\mathbf{2 0 0 6}^{*}$ & $\mathbf{2 0 0 5}$ & $\mathbf{2 0 0 6}^{\boldsymbol{*}}$ \\
\hline Business & 68.0 & 68.8 & 62.7 & 63.8 \\
\hline Government & 11.9 & 11.4 & 29.5 & - \\
\hline Higher education & 17.6 & 17.1 & & \\
\hline
\end{tabular}

Note: *: 2006 figures are provisional.

Source: MSTI 2008-1

Firms innovate to improve performance, by increasing demand or reducing costs (OECD \& EC 2005). New products and processes can be a source of market advantage, and innovations can themselves increase a firm's ability to innovate in other areas (for example, new organisational practices can improve a firm's ability to gain and create new knowledge that can be used to develop other innovations). Innovation may be seen as an aspect of business strategy or part of the set of investment decisions to create capacity for product development or to improve efficiency. Firms may use innovation to position themselves competitively - defending current positions or innovating to gain new strategic market positions. 
However, the ability to create value from intellectual assets is highly contingent on the management capabilities in firms and the implementation of appropriate business strategies (OECD 2008e). Management must direct investment to areas of higher expected returns (since the value of many intellectual assets is highly skewed - a small number of patents can account for the bulk of the value of a patent portfolio), and develop processes to ensure these returns are realised. Leading firms have increased the efficiency of their $R \& D$ processes by linking internal $R \& D$ activities more closely to their business strategy and relying on external sources to gain access to complementary knowledge and round out technology portfolios. A number of firms have achieved considerable revenue growth through the adoption and active implementation of intellectual asset management procedures.

Governments attempt to influence innovation by firms through a number of channels, predominantly direct fiscal support and finance. Entrepreneurship and SME policies are also popular. These are discussed below.

\section{Fiscal support for $R \& D$}

Over time, the use of direct grants to institutions and individual firms has become less important in most economies, with greater emphasis being given to tax measures and the targeting of public funds towards specific projects that are put out to tender (Jaumotte \& Pain 2005a). Studies show there is little consensus as to the effectiveness of subsidies and research programmes. One study of 21 OECD countries found that subsidies had a significant positive effect on business R\&D expenditure only when past R\&D intensity is not taken account of. Subsidies have a greater impact on small firms' R\&D expenditures than those of large firms - perhaps suggesting the funding is used by small firms to support activities that would not otherwise be financed. The OECD's Working Party of National Experts on Science and Technology Indicators (the NESTI group) has proposed a research project that aims to assist governments to better assess the effectiveness of support to R\&D and to explore the impact of changes in the policy mix on the effectiveness of support (OECD 2008h). Preliminary estimates of direct government assistance to R\&D (in research funded by the Canadian Department of Finance) suggest that the value of contracts awarded to firms may be more important in many countries than direct grants and contributions through government programmes.

Government subsidies to the business sector and tax incentives appear to be substitutes. Analysis suggests tax policies can induce higher private $R \& D$ expenditure, with estimates of the elasticity of $R \& D$ to its price varying from 1 to 1.5-1.8 (Jaumotte \& Pain 2005a). However, they do not show that the social gains necessarily outweigh the associated compliance and administrative costs (spillovers from higher R\&D to productivity would raise the chances). There is a higher probability of research duplication with tax reliefs, and research may be less likely to occur in areas of high social returns. In addition, small firms with little taxable income may not benefit. The bigger question is whether the foregone tax revenue could have been better spent elsewhere. There is also a question as to the impact on firm location decisions, and the potential disadvantages for countries that do not offer tax incentives. Work on tax incentives is continuing, with a view to identifying best practices (Box 2). 


\section{Box 2. R\&D tax incentives}

In 2007, some 21 OECD countries offered a tax credit for R\&D, compared to 12 in 1995 . Furthermore, the generosity of these incentives has tended to increase. Providing good policy advice in this area requires a better understanding of the efficiency, effectiveness and impacts of R\&D tax incentives. A recent OECD workshop highlighted a number of key messages:

- Tax incentives are increasingly being differentiated by firm size, with some countries focusing on support for SMEs. Local governments in some countries are also active in providing incentives, raising the overall generosity of fiscal relief for R\&D.

- In theory, the case for an R\&D tax incentive is linked to potential market failures; in practice, the decision to offer an incentive has become more complex and dependent not only on the policy objectives but also on its interaction with other instruments.

- The design of an R\&D tax incentive (which firms, tax base, etc) must be matched appropriately with the policy goals.

- There is a need to move beyond the B-index of generosity and improve measures of the actual cost of incentives (i.e., foregone tax revenue).

- Evaluation of R\&D tax incentives is necessary, especially in view of the rising reliance on this policy and its rising costs to governments.

- The interaction of tax incentives with other fiscal instruments aimed at stimulating innovation needs to be considered.

- The risk of R\&D tax competition is real but its impacts on the tax base have yet to be assessed.

Potential future work on R\&D tax incentives includes: monitoring of incentives; measurement and evaluation; exploring to what extent tax incentives are being used to foster broader forms of innovation; and evaluating the role of tax incentives in the broad policy mix for innovation.

Source: OECD 2008i.

These conclusions are supported by further work, which found that the effect of tax incentives on productivity appears relatively modest, although larger for industries that are structurally more R\&Dintensive (OECD 2008b and OECD 2008j). Tax incentives have a stronger effect on R\&D expenditure than direct funding. One advantage of tax incentives for $\mathrm{R} \& \mathrm{D}$, compared to direct support, is that decisions on projects are undertaken by firms themselves and so are more likely to be successful than governmentselected projects. At the same time, deadweight losses may be larger for tax incentives, and the incentives are generally only available for formal $\mathrm{R} \& \mathrm{D}$, thus having little effect on productivity in the increasingly important service sectors. If tax incentives that attract $R \& D$ are matched by similar benefits in other countries, the overall loss of tax revenue may exceed the benefits to be obtained locally from R\&D externalities or knowledge spillovers from MNEs.

\section{The availability of finance}

As noted earlier, deep financial markets and access to secondary "high-risk" capital markets can assist innovative firms to progress along their growth trajectory. Having access to venture capitalists and "business angels" can provide more than just funding - they also help start-ups to develop as businesses, providing advice and potentially on-the-ground management expertise (OECD 2001b). Some evidence suggests increases in venture capital are associated with higher patenting rates - this may be due to firms patenting to attract financing, but there is also evidence that patents of VC-backed firms are more highly cited (Jaumotte \& Pain 2005a).

In light of this, governments have developed policy programmes targeting fiscal support directly at small firms, and also measures designed to encourage the development of venture capital markets 
(Jaumotte \& Pain 2005a). Reforming stock market regulations to allow the growth of high risk capital markets, which typically have less stringent admission requirements and lower costs than the traditional main markets, and are used by $\mathrm{VC}$ investors to pass along investments that have matured, re-liquify their assets and seek new investment opportunities, can help stimulate VC supply (OECD 2001b). Early-stage financing remains a focus for governments - figures show that venture capital investment by private entities is weighted heavily towards the expansion stage, for growth and expansion of firms that are breaking even or trading profitably (OECD 2007a, p. 39). Seed capital and start-up financing is more scarce.

However, some caution is warranted in this policy area. While seed financing by government or public institutions may have a leveraging effect on private sector risk capital, governments are not the best placed to identify firms in which investment should occur (OECD 2001b). Government intervention in VC may also be ineffective if other important conditions, such as management advice and good business regulations, are missing. Government intervention may crowd out the development of a private sector venture capital market. In any case, evidence suggests that a lack of good projects may be a prime constraint on VC activity (OECD 2003d).

Regarding the market for small amounts of debt or equity, work has found that while some worthwhile projects do go unfunded, market failure in the provision of debt is not widespread (OECD 2003d). Small amounts of equity finance may be problematic, as the costs of administering the investment relative to the potential return may be too high for VC investors. However, demand factors also play a role - a greater willingness on the part of entrepreneurs to accept external equity would facilitate growth and survival for many small firms. The prevailing attitude of SMEs towards financing is a preference for internal funds over debt and equity financing. When external financing is sought, evidence suggests the most common source remains debt financing, both for small firms generally and for innovative SMEs (OECD 2008p). Demand for external equity might be increased through education and tax incentives. Public initiatives to support SME investment for growth and innovation are often centred on improving SME investment readiness (to access equity financing). However, it appears equally important to encourage credit readiness.

\section{Entrepreneurship and SMEs}

Dynamism in firm turnover (entry and exit) contributes to the abilities of countries to expand the boundaries of economic activity, shift resources and adjust the structure of production to meet consumers' changing needs (OECD 2001b). New firms and associated innovations tend to arrive from the interplay of three factors: opportunity (market conditions), skills, and resources (access to capital, R\&D and technology). The degree of entrepreneurship, and its associated new firm creation, differs widely across countries and regions, due to a range of differences in institutions and framework conditions, including financial markets, regulatory and administrative environments, education and training, and cultural and social issues.

Interest in entrepreneurship policy has increased in recent years, as globalisation and the ongoing shift to knowledge economies highlights the importance of innovation and thus of entrepreneurship and firm creation (OECD 2008o). Supporting the creation and development of new businesses is a common measure used to accelerate economic development at a national, regional and local level. Entrepreneurship is one of the keys to economic dynamism - accelerating the process of generating, disseminating and applying innovations in technology and organisation (OECD 2003d). There is some evidence that those countries, regions and localities with greater entrepreneurship rates also tend to have higher rates of employment and productivity growth, although the relationship is not straightforward. 


\section{DSTI/DOC(2009)2}

Rationales for policy in this area are often related to purported failures in markets for financial, industrial real estate, business development and training services, as well as ideas that policy support for entrepreneurship may develop more entrepreneurial cultures. However, further evidence is required to fully understand the policy role. The OECD has made a number of suggestions for good policy approaches to entrepreneurship, including facilitating access to financing and training (since basic managerial deficiencies account for a large part of new and small firm mortality), encouraging use of the internet and ICTs, and offering pre-start advisory and screening services (OECD 1998b). More evidence and evaluation would make a strong contribution to better policy in this area (OECD 2007s).

With respect to SMEs, a review of innovation policy in six member countries revealed several perceptions, in particular: that countries with innovative SMEs were more attractive to large innovative internationally mobile firms; that innovative firms could help sustain the country's overall innovation effort if MNEs decided to move their R\&D offshore; that large established firms have more difficulty in creating new businesses and adopting new business models than do SMEs; and that technology-based SMEs could help regenerate economically disadvantaged regions (OECD 2005c). The policy challenges related to SMEs include financing, taxation, enabling market access and technology diffusion, and framework policies in areas such as regulation, bankruptcy and employment.

\section{Procurement and innovation}

The relationship between innovation and public procurement and the broader question of demand-led innovation measures and policies have until now received relatively little attention, but there is growing interest among policy makers and economists. The public sector is an important purchaser and provider of services. Since innovation is closely linked to demand from users, government as a large scale purchaser can promote innovation by being a demanding buyer (OECD 2001a). The mechanisms through which public procurement affects innovation include signalling acceptance of innovations as early or lead users and creating new markets. The internet is a case in point as its predecessor was the communications system procured by the US Department of Defence. The relationship between innovations and procurement can also be mutually reinforcing as adoption of innovations can improve procurement and delivery of public services by fostering efficiency gains and quality improvements. However, against this, government regulations relating to the tender and its content can discourage risk-taking and innovation. More work is needed to better understand the linkages and potential policy responses to support innovation through procurement.

\subsection{Public research}

Business-funded R\&D has gained in importance relative to government-funded R\&D over the past years and venture capital has become an important source of funding for new innovative firms (OECD 2001b). Publicly funded research has also become more commercially oriented. However, there remains a need for basic research that does not lead immediately to commercial returns. This is the main motivation behind public research - to fund and perform basic research that often has a long time horizon and high risks, with uncertain returns. Expanding research activities in public research organisations can help to support business sector research activities via knowledge spillovers (although these benefits can be mitigated if the wage costs of researchers in the business sector are also pushed up) (Jaumotte \& Pain 2005b).

Public research systems have experienced pressures for change in recent years, as the business sector and civil society have become more active stakeholders in public research and as multidisciplinarity and institutional networking have increased in importance. Effectively adjusting to these pressures, and ensuring the long-term sustainability of public research systems, has required changes to governance structures, priority-setting processes, funding allocation mechanisms, and human resource policies 
(OECD 2003a). While different countries have taken different approaches, reflecting the country-specific characteristics of science systems, some common trends can be seen:

- Countries are involving a broader range of stakeholders more directly in priority-setting processes. While governments should retain a strategic role in priority setting, participation of business and civil society in advisory councils, boards and peer review panels is becoming widespread and formal technology foresight exercises are becoming more inclusive and more common. There is a debate on whether top-down or bottom-up approaches are needed; in practice, there is often a mix of both.

- Countries are restructuring the institutional mechanisms for financing public research, to better facilitate funding of multidisciplinary research and of research that responds to user needs. This has usually involved establishing or reforming the research councils or similar bodies that operate at the interface of government ministries and research-performing institutions, but has also been achieved by improving co-ordination between funding agencies and government, and through specific funds that create incentives for interdisciplinary collaboration or for research in certain priority areas.

- Governments are adapting their mechanisms for financing research. One key area is making greater use of competitively-awarded project funding. By tying funding to specific objectives, this strategy aims to overcome rigidities in the discipline-based research system and enable funding of interdisciplinary and emerging areas that reflect national priorities, as well as contribute to greater overall efficiency, performance and adaptability of research institutions. This has been accompanied by changes in evaluation methods, to include relevance as well as research excellence. While there have been some concerns that this reduces curiosity-driven basic research, it is clear that problem-oriented research increasingly drives knowledge creation, and experience from countries such as the United States shows that project funding is not incompatible with fundamental research. To ensure that financing of research infrastructure is maintained with the move to greater project funding, some countries are requiring funding bodies to pay the full costs of research (including infrastructure and overheads) assessed for each project, while others have established funds for infrastructure spending. Another key area related to financing is a greater use of initiatives to support public-private collaboration and partnerships, in order to better leverage the research investments and results from each group.

- In regards to structures for research performance, countries are making greater use of centres of excellence to support critical mass in specific research areas, to promote multidisciplinary research and to encourage private-public collaboration. Some countries are also restructuring and/or privatising parts of research institutions, and encouraging greater interaction with industry (through the establishment of liaison offices or through changes to regulations around IP).

- Countries are attempting to attract more students into S\&T careers and are adapting graduate education to include more industry involvement. Increased flexibility in employment conditions and in mobility have also been signalled as important. (Human resources are discussed in more depth in section 6).

It will be important to evaluate the impact of these changes.

\subsection{Fostering industry-science linkages}

The innovation system increasingly depends on a sufficient degree of interaction among firms, universities, research institutions and regulators (OECD 2000a). With science exerting a more important and direct influence on innovation, especially in fast-growing new industries, the intensity and quality of industry-science linkages play an increasing role in determining returns on investment (OECD 2002a). 
Motivating linkages on the industry side is the interest in gaining first, and sometimes exclusive, access to new basic research, and in sponsoring or recruiting key scientific personnel (Jaumotte \& Pain 2005a). The benefits of public research for the private sector may vary by sector and by firm and project size (large firms, start-ups and firms with high research intensity are more likely to engage with universities). Firms also need to have the absorptive capacity to assimilate and build on the scientific and technological knowledge generated by public research organisations (PROs). Overall, the weight of evidence suggests that co-operation with PROs is likely to stimulate private sector $R \& D$, with the main benefits coming from mechanisms that improve the flow of information between the two sectors. For universities, the main incentive to collaborate more closely with the private sector is financial, with applied commercial research being a way to attract business research funding and possibly licensing income. An additional factor prompting an emergence of broad alliances between universities and firms, and growing activity in commercialisation of results through licensing of IP and spin-off companies, is globalisation (OECD 2002a).

The key underlying drivers of linkages are the orientation of universities and PROs to the needs of business and the need of business for the outputs of the research base and their ability to absorb and exploit them (OECD 2005c). Some argue that instead of focusing on linkages themselves, policy makers should focus on aligning these "needs" and linkages will follow naturally. Certainly, fostering linkages between universities whose legal framework and internal incentives make researchers uninterested in working with business, and firms who have little need for the outputs and cannot absorb them anyway, will achieve little. However, given the pressures to improve innovation performance, policy makers may wish to act on all factors simultaneously. Linkages are often also shaped by social networks, stemming from the education system (OECD 2002a). These networks exert a strong influence on national and regional patterns of linkages that may exist between MNEs and top universities and between universities and high-tech small firms.

Linkages can be evaluated along three dimensions: the nature and relative importance of the channels of interaction; their incentive structures; and their institutional arrangements (OECD 2002a). On the first, the low rate of mobility of researchers between the private and public sectors remains a bottleneck to industry-science linkages in many countries, but spinoffs from publicly funded research, especially in information technology and bio/medical technologies sectors, are robust. However, more recent work cautions against using spinoffs as an indicator of linkages, noting that there is an increasing body of opinion suggesting most spin-outs are of little economic significance, as their technology base is too narrow and too far from commercialisation for them to develop and grow. Instead, many are a vehicle for further "proof of concept" which could be undertaken by other means (see OECD 2005c). Regarding incentive structures, in nearly all OECD countries there has been a trend towards transferring ownership of publicly funded research results to the agent performing the research (depending on the country, either the research organisation or the researcher themselves). On institutional arrangements, university-industry linkages have enjoyed a comparative advantage, as science-based innovation increasingly requires multidisciplinarity and builds on people-based interactions. Decentralised university systems that have more freedom in their research policy and relations with industry have been more responsive to opportunities for industry-science links than centralised university systems. 
While PROs and industry are best placed to determine how their collaboration can be enhanced in practice, governments have the responsibility for setting basic rules and institutional structures (OECD 2002a). Policies that encourage the diffusion of technology through the economy are essential and regulations that govern science-industry relationships are an important part of this (OECD 2000a). Policy action is important in several areas, including:

- ensuring appropriate frameworks for IPRs - perhaps granting IPR ownership to the research institution but ensuring that individual researchers enjoy a fair share of royalties ${ }^{7}$, and also attempting to harmonise IPR regimes and practices at the international level to achieve greater efficiency;

- $\quad$ supporting the matching of supply and demand for scientific knowledge (for example, by establishing technology licensing offices or fostering knowledge markets);

- improving the governance of universities and public laboratories, in particular by establishing mechanisms for priority setting and funding that reflect industry input (greater university autonomy would benefit many countries) and tying funding to performance (here, evaluation is essential and must look at research quality, its social and economic impact, and its value in educating students);

- ensuring sufficient public access to knowledge from publicly funded research; and

- removing barriers and disincentives to mobility and flexibility in research employment (OECD 2002a).

Private-public partnerships (P-PPs) are one device that may enhance the efficiency of technology and innovation policy by linking industry and science (OECD 2005f). Their major contribution is in developing infrastructure for knowledge and technology diffusion and in supporting collaboration between private firms and public research organisations to undertake R\&D. P-PPs now represent a significant and increasing share of public funding of $R \& D$ in some countries, as governments seek to improve the leverage of public support to business $\mathrm{R} \& \mathrm{D}$, secure higher-quality contributions from the private sector to government mission-oriented $\mathrm{R} \& \mathrm{D}$, foster commercialisation of public $\mathrm{R} \& \mathrm{D}$, and upgrade knowledge infrastructures. P-PPs are the best approach to build innovative networks in new multidisciplinary fields. Critical factors for success include: a long term commitment from both parties, based on a shared vision; achievement of critical mass, but one that is embedded in local and regional innovation systems; use of existing networks; and implementation of efficient steering mechanisms that ensure a sustainable balance between private and public interests. To help choose the appropriate fields for collaborative research and avoid drifts in research focus, governments should ensure: competitive selection of projects and participants, with openness to foreign participation; a financing mechanism that sets a ceiling on government subsidies, but that is flexible, ensures high reciprocal leverage and is long-term; efficient organisation and management, with strong industry involvement; and rigorous evaluation, involving foreign scientific, technological and business experts.

7. It is not clear whether the results of publicly funded research should be made freely available to all or licensed to the highest bidder (OECD 2005c). There is anecdotal evidence from the United Kingdom and United States that attempts by universities to secure too high a price for their IPR have acted as a barrier to exploitation, as firms have preferred to walk away or not negotiate with universities at all. 


\subsection{Regional and sectoral aspects}

Regions

Technological advances and the impact of greater competition have seen opportunities for firm location widen substantially - firms can access inputs and knowledge from a distance, corporate strategies are focusing on more open and networked innovation systems, and offshoring is extending to R\&D (OECD 2007f). In some regions the productive structure has changed, with movement away from manufacturing production towards knowledge-intensive service activities, as productivity gains from technological advances and industry-level restructuring spur adjustment.

But at the same time, geographic concentration remains a striking feature of virtually every national and regional economy in the OECD, as firms tap into localised spillovers. Using data on patents by region, for example, shows that the development of inventive activities in countries usually takes place in a small number of regions, with highly inventive regions tending to cluster together (OECD 2008e). This spatial pattern has increased over time and reflects the importance of geography, since knowledge flows and specific skills often require proximity to be exploited. The inventive performance of regions is directly influenced by the availability of human capital and R\&D expenditure, but also importantly by aspects of national innovation systems (macroeconomic conditions, and policy frameworks on competition, R\&D and IPR). More than half of patents reflect cross-regional co-inventions, with the vast majority organised within firms (essentially large, multiregional and multinational firms).

On average, regional changes have been associated with increases in employment; between 1998 and 2004, two to three service jobs were created for every manufacturing job lost over the period in the OECD, and in some more dynamic regions the ratio was ten or more new services jobs per manufacturing job lost (OECD 2007f). Yet policy makers are concerned about the resilience of regional economies and whether competitive industries can be maintained outside the core regions in which they currently concentrate.

The most important policy objective for regions is to favour adaptation to change - developing an environment that supports private actors in their efforts to adapt and seize opportunities (OECD 2007f). One framework for considering policy at the regional level is the "learning region" (OECD 2001d). This looks at how the emergence of new forms of knowledge-based economic activity are affecting different cities and regions, and how policies can help these areas to adapt, improve their innovative capacity and sustain employment levels and general levels of wellbeing. Part of this relates to learning by individuals, through participation in education, but part also relates to learning that takes place within and between organisations, which is fostered by intensive information exchange and stable, high-trust relationships.

While regions vary widely in the circumstances they face, as a result of their past trajectories of economic and social change, there are some general policy principles that support learning and innovation at the regional level. These include:

- $\quad$ providing high quality general education to upper secondary level and ensuring the curriculum includes skills to enable adults to be lifelong learners;

- considering the demand for skilled workers as well as their supply, so as to avoid excessive labour market mismatches;

- establishing appropriate framework conditions and incentives necessary for firms to engage in organisational learning, for example, by facilitating exchange between firms and organisations that produce knowledge; 
- being open to "unlearning", in particular, avoiding lock-in of policies and practices that better suit past circumstances;

- $\quad$ engaging the populace in any new regional strategy;

- co-ordinating policies across portfolios and across different levels of government, as appropriate; and

- fostering social capital as a key mechanism in promoting more effective organisational learning and innovation (OECD 2001d).

Higher education institutions (HEIs) are also being asked to play an increasing role in supporting the knowledge economy at the regional level (OECD 2007c). This engagement has several dimensions: knowledge creation in the region through research and its exploitation via technology transfer; human capital formation and knowledge transfer; and cultural and community development. While the partnership between regions and HEIs is built on shared interests, active engagement has been constrained by several factors, including the orientation of public policy, inadequate funding and incentives, limits to leadership within HEIs, and the limited capacity of local and regional agents to get involved with higher education. Removing barriers to engagement would support increased linkages between HEIs and their regions and assist regions to take advantage of the opportunities of the knowledge economy.

\section{Clusters}

At the broadest level, clusters are networks of interdependent firms, knowledge-producing institutions, bridging institutions (e.g. providers of technical or consultancy services) and customers, linked in a production chain which creates added value (OECD 1999a). They can be regarded as reduced-form national innovation systems, where system elements help stimulate the emergence of specific kinds of innovation in various segments of a national economy (OECD 2001c). The concept of a cluster is fluid there is no one definition setting out the level of linkages between actors, the degree of resource sharing or the "completeness" of the value chain. Every country or region has its own selection of clusters and specialisations with different characteristics and roles in the economy. With value chains increasingly internationalised, clusters typically transcend geographic boundaries. Technology-based clusters are particularly likely to be part of wider international clusters, while more mature clusters may function primarily at a national or regional level. Evidence suggests that the most significant elements of the value chain responsible for innovation are the firms that trade with each other along the chain as suppliers or customers. Inter-linkages are not necessarily focused on technologies - organisational and marketing knowledge are also shared.

Co-operation in clusters is increasingly required for firms to be successful - it offers a direct way to improve economic performance and reduce costs, and linkages with demanding consumers can play an important role in guiding innovation and technological change (OECD 1999a). But the emergence of clusters takes time, and their birth may be related to particular historical events or to the availability of natural resources; their development trajectories are highly individualised. Thus the role of government is mainly as a catalyst and broker in strengthening cluster formation. In addition to broad framework policies, the government could:

- stimulate knowledge exchange (eg via technology foresight activities, discussion platforms, websites);

- $\quad$ use direct intervention to ameliorate market and systemic failures;

- $\quad$ act as a demanding customer in the area of public needs; 
- $\quad$ strengthen co-operation between science and industry; and

- reduce or remove legislative barriers that prevent co-operation or act as a barrier to innovation (OECD 2001c).

Enabling labour mobility is also important, since it helps propagate innovations across clusters (OECD 2001c). The form of facilitation by policy makers in these different areas may differ over the lifetime of a cluster, as the constellation of actors and the particular issues faced can vary over time.

Cluster policies reinforce the need for a horizontal approach to policy making (OECD 1999a; OECD 2007d). Many policies that shape clusters lie outside formal "cluster policy" or even technology policy for example, a construction cluster may be heavily influenced by macroeconomic policies, building regulations, energy policy and fiscal policy (OECD 2001c). There is a need to look at a wider array of policies and their interactions in policy systems. Bringing about changes in government regulations that act as a barrier to innovation in a specific cluster can quite often be as effective in spurring innovation as more specific innovation policy tools.

A recent review of regional innovation highlighted that evaluation of current cluster approaches remains inadequate (OECD 2007d). National- and EU-level programmes are supporting clusters through regional policy, S\&T policy and industrial policy - they variously target particular places, sectors or actors, and attempt to engage actors, provide collective services and fund larger-scale collaborative R\&D projects. A lack of evaluation makes it difficult to assess whether these programmes are appropriate, realistic and flexible enough to achieve their goals. The review found that the stated goals of cluster programmes are often vague or broad, and this lack of clarity makes it difficult to select the right targets and establish appropriate funding levels and durations. There needs to be a compelling reason for why a cluster policy, as opposed to another policy that may be open to all firms, is the most appropriate to achieve the desired goals. There are risks involved in cluster policies, related to insufficient private sector engagement - the long-term effectiveness of policies depends on the private sector continuing to act after a programme ends, and indeed it is the private sector that is best equipped to react in a timely manner to market changes. Some evaluation material noted an excessive public sector role and unsuccessful exit strategies. There are also general risks, such as the ability of the public sector to pick winners, and the potential locking-in of existing clusters and technologies.

Measurement of clusters is an area for further analysis, particularly where value chains cross national borders (OECD 2001c). Indeed, one of the most pressing challenges for the cluster approach is how best to deal with strongly internationalised clusters. Cross-border policy co-operation for cross-border clusters may be required.

\section{Sectors}

Policy needs vary across technological fields and industry sectors. The challenge is to understand the idiosyncratic properties of particular areas so that a consistent and transparent policy mix can be designed, one which combines generic innovation policies with customised policies adapted to the characteristics of the sector. A study of the pharmaceutical biotechnology sector, for example, found that in addition to robust framework and general innovation policy (such as transparent and stable regulations, and promoting industry-science linkages), policies that facilitated a more active role of patients and/or their organisations in innovation processes, clinical trials and market access, and that stimulated the exploitation of public sector biopharmaceutical research, would also be of value (OECD 2006d). In another example, country case studies on hydrogen fuel cells revealed a wide diversity in the structure of national innovation systems for this technology, reflecting: different motivations for pursuing research in this area (in turn, shaped by resource endowments, industrial structures and national priorities); different institutional structures for science, technology and innovation; different industry structures; and different capabilities in the private 
and public sectors (OECD 2006c). It was recommended that governments formulate policies to help increase national benefits from globalised innovation activities, foster P-PPs, develop human resources, and contribute to codes and standards and consumer education.

The service sector is one important area where fine-tuning could be required. In general, government policies have traditionally focused on facilitating R\&D and technology diffusion in sectors such as manufacturing and in larger firms. Given the significant differences between the process of innovation in services and other sectors, governments need to remain aware of these differences and of the characteristics of services when designing and implementing policy instruments. Some instruments of government policy may need adjusting, to remove implicit policy biases against services.

However, policies to facilitate innovation in services should only be developed and implemented if there is a market or systemic failure that prevents optimal levels of expenditure on innovation (OECD 2001a). Levels and patterns of innovation differ significantly from one service sector industry to another, and policy makers need to take a broad approach to encouraging innovation, aiming not just at stimulating knowledge creation and diffusion, but also at developing human resources and entrepreneurship (OECD 2005e). Analysis has highlighted a number of policy areas for attention, noting some services-specific features as follows:

- Service-sector innovation derives less from investments in formal R\&D and draws more extensively on acquisition of knowledge from outside sources, acquired through purchases of equipment and intellectual property. Governments could establish R\&D programmes related to the needs of the more R\&D-intensive segments of the service sector (such as business services), promote R\&D related to the application of ICT to other innovative service industries, and conduct research on non-technical aspects of service-sector innovation, in particular organisational innovation.

- Human resource development is especially important to knowledge-intensive service firms, given their high reliance on highly skilled and highly educated workers.

- The role of newly established firms in innovative activity is greater in services than in manufacturing, so that entrepreneurship is also a key driver of service innovation. Nonetheless, small firms tend to be less innovative than larger firms.

- IPR protection has drawn considerable attention, especially as it relates to software and business method patents, which seem to have strong links to innovation in services. While the effect of different policy regimes on service sector innovation is uncertain, it is clear that changes in policy regimes governing software-related patents and business method patents would have an effect on the service sector, regardless of activity.

\subsection{Governance issues}

Good institutional arrangements can help to improve policy co-ordination, enhance transparency and information flows within the economy, improve the efficiency of government action and reduce systemic mismatches (OECD 1999a). Achieving consistency and credibility in science and innovation policy depends on the extent to which co-ordination between ministries can be ensured and whether various stakeholders can be involved in policy formulation.

With increasing globalisation, the heightened importance of innovation in economies, and the more recent focus on innovation systems (with their associated linkages and interactions), governments have been driven to reconsider their innovation governance and policy making structures (OECD 2005b). For individual countries, what are required are coherent innovation policy agendas that span ministerial boundaries, supported by better evaluation and learning practices. A study of innovation policy and 
performance in 6 countries clearly showed that in the absence of good co-ordination, a proliferation of policy instruments emerges, making the system of support complex and difficult for business to understand, and imposing extra administrative costs on both business and government (OECD 2005c). A study of the pharmaceutical biotechnology sector noted the importance of innovation in the innovation policy governance system itself - in particular, closing the co-ordination gap between separate departments that deal with specific aspects of the innovation chain, and between national, international and regional governments (OECD 2006d).

However, there are a number of challenges in achieving coherence and co-ordination - notably, competing rationales and imperatives across policy domains, fragmentation of government institutions, and a mindset that regards evaluation as an ex-post legitimisation of policy rather than an opportunity to gather and use policy-relevant knowledge in decision-making processes. Government capabilities need to be improved in the areas of:

- balancing imperatives (in particular, economic growth and social/environmental concerns);

- creating visions that clearly communicate rationales, objectives and preferences;

- developing appropriate knowledge bases that are shared across ministries;

- developing a horizontal approach;

- integrating learning and evaluation into policy making and developing action plans with robust monitoring and reporting systems;

- designing agencies to ensure flexibility and long-term policy competence; and

- developing pragmatic public-private sector interfaces (OECD 2005b).

\section{Evaluation and impact assessment}

There is a growing demand for evidence-based policies and evaluation of the performance and impacts of public investments in the economy and society, including R\&D investments. This is partly driven by tighter budgets and an increased emphasis on transparency and accountability, as well as by a desire to better understand the impacts of government spending and activity.

However, effective evaluation of public programmes to support research is difficult (Jaumotte \& Pain 2005a). Ex-post assessment of the activities of grant holders, for example, is often subject to problems with selection-bias - grant holders may be selected on the basis of their research history or on the projected quality of their project. Successful delivery of research results may therefore reflect factors other than the availability of public funding and, in fact, the project may have been undertaken successfully even without funding (suggesting the additionality of the funding is low or non-existent). Tax incentives also pose issues for evaluation - while they are less likely to "crowd out" private R\&D spending (as they reduce the marginal cost of R\&D), they may distort the project choices of firms and may impact on the prices of inputs. Attempting to evaluate the level of spillovers is also difficult, although studies using data at higher levels of aggregation may be more likely to capture indirect spillover benefits than studies using firm level data. And given the range of policies operating simultaneously, disentangling individual policy impacts is extremely challenging.

Assessment of the impacts of public R\&D can generally be undertaken at three levels: the overall research system, public research organisations, and research programmes (OECD 2008s : Chapter 4). There are many dimensions of impact that can be explored - dimensions related to science, technology and the economy are the most common, but there are also dimensions related to culture, society and environment, among others, which are harder to measure but which provide a wider view of impact. In 
assessing impact, it is important to make the distinction between publicly funded and publicly performed R\&D, since the objectives and scope of activities is different and will affect the returns. The choice of methodology is context-specific and using a variety of methods to assess different impacts can be recommended. In general, top-down approaches (especially econometric and mathematical models) are better suited to assess impacts at the system level, and may be used to assess ex-ante systemic impacts. When the objective is a research programme or institution aimed at a specific output, bottom-up methods are favoured - identifying and measuring all benefit sources and mechanisms by surveying potential users becomes easier and so does the calculation of the impacts. Case studies may be used for programmes or institutions aimed at multiple outputs, and are also the best current option for assessing non-economic impacts of public R\&D.

As already noted, evaluation is sparse in many areas of innovation policy, and much more work is required to assess the return on government investment in the innovation activities of firms. In general, micro-econometric studies have shown strong returns to private R\&D investment and the presence of strong spillover effects that generate substantial economic benefits. The evidence is less clear on public R\&D investments, perhaps because the spillovers generated by such investment show up only at the aggregate national level. Macro-level studies have shown high social returns for private $R \& D$, but mixed results for public R\&D, with suggestions that public R\&D only affects economic performance through its impact on private R\&D (OECD 2008s : Chapter 4).

\section{Human capital}

Human capital represents the knowledge, skills and health embodied in individuals that facilitate the creation of personal, social and economic wellbeing (OECD 2001f). The role of human capital as a central pillar of the development process is clear - as the skills and competencies embodied in workers improve, so too does labour productivity (OECD 2001b). It also contributes directly to non-pecuniary benefits such as improvements in health, better parenting and more social and political engagement (OECD 2001f). The role of human capital has received new attention recently, due to its complementarity with new technology - for example, for ICT to be developed and used effectively, the right skills and competencies must be in place (box 3) (OECD 2001b). To take advantage of the growth potential of new technology, it is essential to intensify efforts to upgrade human capital.

\section{Box 3. ICT skills and employment}

ICT skills have increasingly become a requirement in the workplace. Around $5 \%$ of total employment is in ICT specialist occupations (typically requiring ICT specialist skills in combination with other skills such as business or marketing) and around $20 \%$ in ICT-using occupations in a wide variety of sectors.

Basic ICT skills are acquired through the general diffusion of ICTs and their use in schools, and efforts are being made to expose older workers to ICTs through training programmes. For specialist skills, however, it is thought that formal education may not offer sufficient flexibility to adapt curricula and that private sector schemes are better placed to provide training in this area. Outsourcing or offshoring of ICT-intensive activities is another way of accessing ICT or ICT-related skills. Up to $20 \%$ of all people employed carry out the kinds of tasks and functions that could potentially be carried out from any geographic location owing to technological advances in ICTs and the increased tradability of services.

Countries appear to have reasonable policies in place for ICTs. This includes promoting basic ICT skills through the use of ICT in schools, but also for the population as a whole; initiatives for industry-based training for more specialist skills undertaken in conjunction with professional bodies and industry associations; and improving labour market information.

Source: OECD 2006e, Chapter 6: ICT Skills and Employment. 
One of the standard (albeit imperfect) measures of human capital is the number of years people spend in education. Education is fundamental for both the conception and the implementation of innovation, and the ability to adapt to new technology begins with a well-performing compulsory school system, which provides students with strong skills in core fields including mathematics and science. A well-performing and broadly accessible education system at the tertiary level is also important to facilitate the adoption and widespread diffusion of innovation (OECD 2006a). And education and training systems also have a key role to play in creating positive attitudes towards entrepreneurship and in providing adequate managerial skills targeted at start-ups (OECD 2001b).

However, most developed countries are now nearing the limits for how long young people can spend in education. Increasingly, the differences in human capital between countries will depend not on the quantity of education, but on quality - the success of education systems at developing people's full talents and abilities across the course of their lives, from preschool to the workplace (OECD 2007i).

Policy directions on education appear well established. An important starting point is that, as the effects of human capital on wellbeing can take a long time to appear, in terms of both the benefits of investment and the costs of degradation, a long-term policy perspective is required (OECD 2001f). Ensuring a solid foundation in basic education, starting with early childhood education and ensuring that young people exit education with at least an upper secondary qualification; strengthening the links between higher education and labour markets and putting a stronger emphasis on cost effectiveness of education spending; and strengthening the incentive to invest in training and adult learning, are all important facets (OECD 2001b). Incentives for continual learning (such as financial and tax incentives, innovative forms of co-financing, etc), are also important (OECD 2001f). Public support for basic scientific research remains important to increase the stock of fundamental knowledge and to provide highly skilled graduates. Scientific institutions are also important for technology diffusion and innovation and are of increasing importance for countries that want to benefit from the global stock of knowledge (OECD 2000a). In addition, with increasing demand for teamworking ability, flexibility and the capacity to innovate and manipulate knowledge, curricula and teaching methods need to give weight to inter-personal and other non-cognitive skills alongside cognitive skills. One issue for policy is the impact of social background on education. Family circumstances and social background are a factor in the amount and type of education that people undertake (OECD 2007i).

As noted earlier, to fully realise the potential of human capital, it is often essential to reorganise work within firms (OECD 2001b). New work practices such as teamworking, employee involvement and flatter management structures, are associated with ICT use - the common element being a greater degree of responsibility of individual workers regarding the content of their work. Wages and working conditions need to become more flexible to fit with this new way of working. It is also important to allow for sufficient inter-firm mobility, to enable new business opportunities to be seized. In this regard, there is a need to adjust employment regulations in some countries.

With human capital a key factor in the innovation process, it is a concern that many innovation surveys suggest that the lack of skilled personnel is a principal barrier to innovation (OECD 2000a). Innovation in services relies particularly heavily on an appropriately skilled workforce (OECD 2001a). The growth in service activity, with its shift away from low-skilled jobs and towards more knowledge-intensive professions in some countries, has raised concerns that skill shortages could constrain innovation in services. However, circumstances differ across countries and sectors and it is useful to accompany firm survey data with other measures of human capital. For example, initial work shows that the share of low skilled employment in the service sector increased in the United States and the EU15 from 1997 to 2005, and the skill composition of overall employment has been stable in the OECD over the same period (OECD 2007r). More work is needed to fully understand the supply of, and demand for, different skill levels in the service sector. 
Sourcing human capital from abroad is one way for countries to increase the stock of skilled workers. Most OECD countries perceive retaining and attracting HRST as important, and offer a number of policies focused on assisting and encouraging mobility (see OECD 2008r). These include economic incentives to encourage inflows, immigration-oriented assistance, recognition procedures for foreign qualifications, and social and cultural support for migrants. Removing barriers to short-term and circular mobility, and fostering connections with the diaspora, might help to enable mobility and would support knowledge flows associated with brain circulation and the diaspora. But with a growing number of countries seeking to attract the same set of highly skilled workers, such as scientists and engineers, relying on international flows and mobility policies to fill existing or future gaps in the supply of HRST may be a risky approach. Action must also focus on addressing shortcomings in national policies that may limit the supply of HRST.

Gaps remain in the knowledge and understanding of human capital. Further work could usefully be undertaken in: measuring human capital, especially competencies such as teamwork, problem-solving and ICT-skills; and understanding how demand for human capital is changing (OECD 2001f).

\section{Social capital}

Social capital (box 4) refers to the norms and networks facilitating co-operation either within or between groups (OECD 2001f). The concept is complementary to human capital - strong communities and ties among parents, educators and pupils foster learning, while education and learning support habits, skills and values conducive to social co-operation and participation. As with human capital, the effects of building or degrading social capital can take some time to appear. Policy directions are less clear; however, ideas worthy of further development, piloting and evaluation include: support for families (eg. flexible working hours); support of voluntary initiatives (both through encouraging funding and enabling participation); and empowering citizens to participate in government decision-making processes. More work could usefully be done on: extending the conceptual development of social capital, including its measurement; clarifying the links between human and social capital; and evaluating policies to gain a better understanding of what works in promoting social capital. Understanding more about how social capital operates at the firm level, and within networks of firms, would also be useful.

\section{Box 4. Social capital}

There is no single definition of social capital and a number of conceptual approaches have been taken in the literature, spanning contributions from economics, sociology, political science and anthropology. In 2001, the OECD offered its own definition of social capital as:

"Networks together with shared norms, values and understandings that facilitate co-operation within or among groups" (OECD 2001f, p. 41).

Social capital allows individuals, groups and communities to resolve collective problems more easily. It is correlated with better health, improved child welfare, lower crime, better government and higher measures of "happiness". A key factor is trust, which can be viewed both as a source and an outcome of social capital - in the absence of trust, individuals tend not to co-operate because others cannot be relied on to act in a similar way. Social capital has positive externalities, such that many people benefit from the contributions of one individual or group, and thus it risks underinvestment since the contributing actors do not fully appropriate its benefits. Three basic forms of social capital have been identified: social bonds, bridges and linkages. Both bonding and bridging social capital are needed to avoid social fragmentation. Bridging capital allows people to join the key social networks of access and influence and may be critical to the success of some communities.

Social capital resides in social relationships entered into voluntarily, implying that governments will often be facilitating or supporting the development of social capital, rather than actively creating it. Research is still at an early stage of development and cannot point to any clear policy direction.

Source: OECD $2001 f$. 


\section{Challenges for the education system}

How well do education systems meet the human capital needs of economies? One source of information to help answer this question is the results of PISA - the OECD Programme for International Student Assessment. PISA assesses the extent to which students near the end of compulsory education have acquired some of the knowledge and skills that are essential for full participation in society, focusing on student competencies in the key subject areas of reading, mathematics and science. PISA seeks to assess not merely whether students can reproduce what they have learned, but also to examine how well they can extrapolate from what they have learned and apply their knowledge in novel settings. Together with the PISA 2000 and PISA 2003 surveys, PISA 2006 completed the first cycle of assessment in the three major subject areas. The 2006 survey covered the 30 OECD countries plus 27 partner countries and economies, offering a wide picture of student performance.

PISA 2006 identified several school and system factors that had effects on science performance ${ }^{8}$ both before and after accounting for the socio-economic context:

- Science performance was better where school principals reported: academic selectivity in admitting students; publicly posting school achievement data; higher in-school learning time spent on science, maths and language and higher levels of student self-study; and school activities to promote science, such as science clubs, field trips etc;

- Science performance was lower where school principals reported grouping students by ability in all subjects; and

- Science performance was better where schools had a higher degree of autonomy in budgeting (OECD 2007j).

The study also found two school factors that influenced the distribution of learning opportunities:

- Students in schools with longer in-class learning time tended to perform better than students in schools with average in-class learning time, regardless of their socio-economic background; and

- Countries that divided students into different school groups at relatively early ages increased the socio-economic differences in results without leading to gains in overall performance.

Overall, about one-quarter of variation in students' science performance can be associated with the ways in which student learning time, promotion of science, public posting of results, ability grouping, student selection and school budget autonomy vary across countries and across schools, once demographic and socio-economic factors are taken into account. The potential for improving results through such factors needs to be considered in combination with the extent to which schools with favourable characteristics are being accessed mainly by more advantaged students. The policy challenge is to find ways of spreading such characteristics to a wider section of the student population.

What are some of the other future challenges for education systems? The central role of knowledge in the economy has clearly raised particular issues. Schools must redefine their roles to help build and service a knowledge-based society, and develop greater capacity to adapt to change and new challenges (OECD 2000b). This is particularly important, since education systems are strongly rooted in historically established cultural traditions, and the characteristics of these systems underpin many differences in national innovation systems. To meet new challenges and to better produce, disseminate and use knowledge in the education sector, there needs to be closer partnerships between researchers and

8. The results were similar for reading and mathematics. 
practitioners, and teachers' learning must be continuous. Lessons may be available from other sectors, and educators need to become part of wider networks in which ideas about how knowledge can be produced and applied are exchanged.

Work on innovation in education has identified four innovation sources that, as well as being important drivers of innovation in the economy generally, are also relevant for transforming the education sector (OECD 2004c). They are: scientific knowledge; "users and doers", particularly new agents that are becoming involved in innovation processes; modular structures, which individually have the freedom to innovate but which are also joined together in a whole system; and ICTs as a general purpose technology. More use could be made of each of these sources of innovation to improve education systems. One issue that will have to be addressed is defining the boundaries of public knowledge and ensuring that privatisation of knowledge does not limit innovation in the education sector.

The increasing pervasiveness of ICT in the economy has also placed demands on the education system. For example, it has necessitated the adoption of ICT in schools, so that future workers better meet the needs of the employment market and are able to participate in society (OECD 2001e). At the same time, ICT has provided opportunities, increasing the breadth and richness of learning in schools and offering new ways of teaching. E-learning at tertiary institutions, while still representing a small share of total enrolments, has received positive student feedback and has the potential to improve teaching and learning at this level (OECD 2005a). Infrastructure and funding, as well as stakeholder scepticism about the pedagogic value of e-learning and staff development, are challenges for policy. Open educational resources (OER), where digitised materials are offered freely and openly for educators, students and selflearners, are also increasing and offer a way for non-traditional groups of students to participate in higher education. They also support the development of life-long-learning (OECD 2007e).

Improving the knowledge base in education for both teachers and policy makers is essential in order to improve the performance of this crucial sector. OECD countries have taken some initiatives, including putting more focus on "use-inspired research", attempting to better manage and disseminate knowledge, building capacity amongst practitioners, researchers and policy-makers to generate and use education research, and encouraging more collaboration and co-operation between researchers and teachers so as to improve the research base (OECD 2003c). But there are still major knowledge and cultural changes needed in the practice of teachers, researchers and policy-makers in order to create a system-wide continuous improvement of the knowledge base for the education system. A subsequent challenge is to better utilise this research and evidence in policy-making, so as to make education systems better equipped to meet social demands and to respond to change. Some recent country examples and experiences related to brokerage agencies and national research programmes are available (OECD 2007h). More use of evidence may lead to innovation in education and training - potentially contributing to improved productivity and outcomes from this major service sector.

\section{Measurement}

The OECD has a vast amount of information on country innovation inputs and outputs. Country reviews, as well as regular Scoreboard and Outlook publications (such as OECD 2007a, OECD 2006e), present a picture of innovation effort and performance across the OECD, and increasingly across nonmember economies. The statistics show some countries clearly ahead in terms of outputs (patents, publications etc); they also highlight other countries that are catching up with inputs (R\&D spending) but are not yet reaping the rewards.

It is clear that aggregate measures of R\&D spending are a misleading indicator of innovative activity for two reasons: they are influenced by industrial structures; and much innovative activity is not captured by R\&D spending. In any case, looking at the amount of resources devoted to R\&D is not sufficient to 
assess a country's innovation outcome, since this depends on how efficiently resources are used. Measures of innovation performance, such as patents, get closer to this (OECD 2006a). It is also clear that better statistics for services are required. A move from traditional sectoral approaches to definitions that better capture the interaction of services with other industries and the characteristics of innovation in services appears to be required (OECD 2001a).

The new realities of science, technology and innovation are also challenging the statistical STI indicators' focus on the activities of specialised R\&D institutions and the particular national location of such activities (OECD 2007b). It is now more difficult to differentiate between "novelty" and "routine", and improvements are often made outside formal R\&D departments. In addition, over time, the complex sectoral origin and nature of innovation has made popular technological classifications of high/medium/low-R\&D intensive industries somewhat less useful. A low-R\&D industry may be a large user of knowledge generated elsewhere - this holds true for many service sectors, where the introduction of new processes, organisational structures, or product innovations, is unlikely to involve much formal R\&D investment. Rendering statistical systems more flexible and responsive to the introduction of new and fast evolving concepts that are typical of the STI field is crucial to keep up with the changing context. In addition, the link between the location of "national" firms' private R\&D activities and a country's productivity gains appears increasingly loose, for small and large countries. The largest part of worldwide productivity growth in the last decade has been associated with acceleration in the diffusion of technological change and with global access to codified knowledge. One of the greatest challenges to policy makers is to acknowledge more fully the global public good of STI.

At the Blue Sky II Forum in 2006, contributions and discussions were clearly centred on innovation a term covering science (the basis for some but not all inventive activity), the diffusion and commercialisation of product and process innovations, and the implementation of non-technological innovations in marketing and organisational practices (OECD 2007b). The Forum's appraisal of the current supply of innovation indicators was a critical one. With the exception of several under-exploited indicators obtained from innovation surveys, the available range of indicators is almost entirely limited to inputs, innovative activities, and intermediate indicators that measure invention or the disclosure component of the innovation process (such as patents and bibliometrics). The state of measurement prevents a full understanding of how innovative activities lead to social and economic impacts, which is a necessary prerequisite to the development of appropriate and coherent policies. Four key messages were sent from Blue Sky participants to the wider STI community:

- Research on innovation in the broad sense is currently fragmented. There is a need for a general framework of analysis and greater co-ordination of research efforts. The goal is to understand the entire story of innovation, from inputs to economic and social impacts;

- Indicator and related econometric research must move forward from innovation inputs and activities to include the outputs and impacts of innovation;

- New methods of analysis are necessary to understand innovation processes, which will require improved data access, data linkages and the adoption of interdisciplinary approaches to data; and

- A marked improvement in the policy relevance of innovation research is required in order to create a science of science policy.

The OECD plays a central role in each of these four areas and responsibilities range widely across the organisation (OECD 2007b). The NESTI group works directly on STI indicators and, at present, is working to advance statistics and analysis in the areas of $R \& D$ capitalisation in national accounts, measures of indirect support to R\&D, commercialisation of public and private research, and measurement guidelines in HRST, as well as exploiting the potential of existing data in the innovation surveys undertaken by countries. A clear message coming from the latter project is the need to grant greater data 
access to micro data for analytical and policy relevant purposes. Where this is already occurring, there have been valuable gains in knowledge of firms' innovation activities, especially in newer, less-studied areas such as non-technological innovation (see box 5). Another clear need is to improve involvement from the policy community, whereby users influence indicator design and identify data gaps and priorities for new indicators.

Many other OECD groups also produce relevant statistics and analyses that advance the measurement and understanding of STI issues. For example, there is work on measuring firms' knowledge management practices (OECD 2003b), the measurement of eco-innovation (OECD 2008u) and identifying firms' skill needs. The need for co-ordination of research efforts goes far beyond research by and for the STI community.

\section{Box 5. Microdata: Exploring innovation through firm-level data}

The OECD Innovation Microdata project is the first large-scale attempt at exploiting firm-level data from innovation surveys for economic analysis in a harmonised way. Research teams for around 20 countries have worked using similar methodologies to examine topics such as innovation and productivity, international technology transfers, non-technological innovation, and innovation and IPRs. The project also involves the collection of internationally comparable statistics from recent innovation surveys and the development of new indicators. Analyses using firm-level data can shed light on aspects of innovation that have received less attention in the literature so far than have pure technological dimensions based on R\&D and patent analyses. They also reflect the heterogeneity of firms, and thus provide crucial knowledge for the design of innovation policies.

For example, using firm-level data allows a deeper exploration of the complementarities between technological and non-technological innovation and their impact on firm performance. An initial study of nine countries found that all countries exhibited some form of "new-to-market innovating" mode, where firms introduce a new-to-market innovation that has been accompanied by in-house R\&D and patenting. A number of countries combined externally acquired R\&D with their own technology in this mode, and several also showed strong use of design-related activities. Other modes of innovation revealed by the data were "marketing-based following", "process modernising" based on embedded technologies and training, and "wider innovations" linked to organisational and marketing innovations. In almost all countries, there was a group of firms that engaged in all these types of innovation, as well as groups of firms which were specialised in terms of their innovation strategies and tended to follow one specific mode of innovation.

Source: OECD (2008s): Chapter 5; OECD (2008n)

\section{Looking ahead: Global challenges}

The global dimension of innovation is underscored by the emergence of policy challenges that require a global perspective, such as climate change, energy supply, health, security and water. Governments increasingly look to innovation, science and technology for solutions. The complexity and scope of these challenges require international co-operation to leverage the impact of national efforts.

For example, one of the major challenges facing all countries is related to the environment. Issues of energy consumption, pollution and $\mathrm{CO}_{2}$ emissions are growing in importance and eco-innovation (via new products, processes, organisational structures or business environments) offers considerable promise for facilitating the decoupling of economic growth from long-term environmental degradation. There is growing interest in topics such as sustainable manufacturing, where the producer accounts and takes responsibility for the economic, environmental and social effects of all functions and operations provided or undertaken by the company (OECD 2008f). (However, existing schemes or approaches to sustainable manufacturing suffer from a lack of systematic measurement, and rhetoric and public relations play a larger role than commitments to real change). There is also interest in the use of general purpose

9. A workshop was held on 22-23 May 2008, in conjunction with the European Centre for the Development of Vocational Training (Cedefop), to discuss next steps on finding a common European approach to using employers' surveys to identify skill needs and skill gaps. 
technologies, such as ICT, biotechnology and nanotechnology, in addressing environmental concerns (box 6).

\section{Box 6. General purpose technologies and global challenges}

General purpose technologies such as ICT, biotechnology and nanotechnology may play a crucial role in addressing global challenges. With respect to eco-innovation, for example, ICT offers major opportunities for improving environmental performance and monitoring, managing and reducing environmental burdens. The application of ICT can improve energy efficiency, better organise resources in production, enable remote communication to replace some physical flows of people (and use of physical resources), and support and enable environmental and social research. At the same time, the production of ICT equipment and related waste, and energy consumption in use, produce negative impacts on the environment - establishing incentive structures and policies that encourage good applications of the technology can ensure that beneficial outcomes are maximised and harmful ones minimised (OECD 2007o). Application of biotechnology and nanotechnology to industrial products and processes also offers opportunities for environmental improvements, although nanotechnologies are still at an early stage and require more analysis of their physical/technological properties and risks, as well as how best to treat the technology from a policy perspective (OECD 2008f).

Much innovative activity related to the environment is already underway. Currently, water and air pollution innovations are dominating environmental patent activity (see OECD 2008u). The key determinants of environmental patenting activity appear to be general scientific capacity, overall market factors (such as factor prices), public demand for environmental goods, and environmental policy (although effects differ across innovations). The type of innovation is changing over time, with different "generations" of innovation. International diffusion of environmental innovation is common (for instance, the transfer to the US of Japanese technologies related to motor vehicle emissions is large).

Trade and investment can promote new environmental innovations and encourage their diffusion. This is particularly important in the context of developing countries, whose production and consumption is rapidly increasing and where the risk of lock-in of older, less efficient technologies is high. Trade in goods and services that embody environmental technologies is one key channel of diffusion. A second is that the creation of a bigger market through trade may provide sufficient economies of scale to invite further R\&D investment in environmental technologies. There is a certain level of tension between the promotion of the creation of new environmental technologies and the promotion of the diffusion of innovation. This tension was evident in the context of the discussion of trade-related intellectual property rights (TRIPs) and public health, where the need to maintain an incentive for pharmaceutical companies to develop new drugs was balanced with the need for poor developing countries to have access to affordable drugs.

The rationale for government intervention in environmental issues is the existence of market failures that may lead to sub-optimal amounts of innovation with beneficial environmental impacts, in particular, the inability of inventors to reap the full profit from their inventions, and the environmental externality itself (OECD 2008v forthcoming). Addressing the first form of failure implies making sure innovators get credit for their inventions that are of value to society-at-large, and addressing the second implies "getting the prices right", so that the costs and benefits of actions are clear. The ability to internalise externalities depends on both efficient markets and regulations (e.g. setting the price of $\mathrm{CO}_{2}$ emissions to foster investment in R\&D). Recent work on framework policy conditions to promote environmental policies that are efficient and effective offers some general lessons for policy in this area (OECD 2008v forthcoming):

- With regard to public financial support for environmental goods and services, this should only be provided in cases where public goods are expected to be generated, and consideration should be given to whether such support is the most economically efficient way of reaching the given environmental target. Generally, policies that require polluters or users of environmental services to pay for the environmental problems they generate are preferable to subsidies (note that the 
design of "pro-innovation" signals seems to be as important as the signal itself $\left.{ }^{10}\right)$. When providing support, it is important to define a base reference level, beyond which performance is considered to have improved, to assist in policy evaluation and administration. Policy makers should check that support programmes do not have the secondary effect of directly or indirectly encouraging additional demand for, or supply of, polluting products or activities in the long-term. They should also consider ways of allocating support so as to obtain the maximum environmental improvements for a given amount of support - undertaking cost-benefit analysis, or instituting bidding processes in the allocation of subsidies, are some options.

- With regard to support for environmental technologies, policy makers should consider how to provide ongoing incentives for innovation. Some countries use emission or performance standards, however, once polluters are in compliance with these standards, they normally do not have any incentive to make further improvements. Conversely, if an economic instrument (such as a tax or a tradable permit system) were applied, an ongoing economic incentive would be imposed on polluters (although in a cap-based trading system, if the cap remains unchanged, improvements generated by one participant will be offset by higher emissions elsewhere in the system). Public financial support may be useful to encourage basic research activities, but governments should be reluctant to "pick technology winners", since support for specific technologies can create powerful pressures for maintaining support long after the social returns have dissipated. An "enabling framework" for the overall innovation environment, which adequately protects IPRs and supports a well-functioning education system, is crucial.

In formulating policy, analysis has suggested that governments should be aware of the motivations driving actors in the innovation system, and should not be too quick to impose specific solutions where a general framework may suffice. An empirical assessment of public policy frameworks and environmental management, innovation and performance among firms in seven OECD countries found that firms are strongly motivated by the possibility of reduced inspections (OECD 2007g). (Indeed, government regulation seems to be a key driver for environmental innovation - see OECD 2008k, although there is also evidence that "environment-minded" firms do act independently, so as not to alienate "green" consumers and to be ready to face the risks of "embedded" environmental liabilities - see OECD 2008m.) The assessment also found that the effect of environmental management systems on environmental performance can be overstated, and the value added of specific environmental management tools over general management tools is not yet clear. Mainstreaming environmental matters into everyday management structures is perhaps of more importance - indeed, it was found that one of the key determinants in the decision to invest in clean production (rather than end-of-pipe abatement) was the degree of mainstreaming. Looking at environment-related R\&D revealed that environmentally innovative firms are innovative firms in general - what drives innovation overall also drives environmental innovation in particular. Exposure to international market opportunities appeared important.

The variety of approaches across OECD countries, with different mixes of instruments and policies and different emphases on the role of the public sector, offers clear opportunities for learning (OECD $2008 \mathrm{w}$ forthcoming) ${ }^{11}$. Innovative policy instruments have emerged and more needs to be learned about their performance and the potential for replication. Analysis has revealed the tension between the need to compete on the development and diffusion of eco-innovations and the need to collaborate internationally in order to maximise the net benefits of global eco-innovation.

\footnotetext{
10. See OECD $2007 \mathrm{~m}$.

11. The OECD's Environment Directorate has also looked at recent developments in environmental innovation in China - see OECD 20081.
} 


\section{DSTI/DOC(2009)2}

More broadly, countries are seeking to understand how to leverage off national efforts and ensure national benefits flow from globalised innovation efforts. There are a host of complex "international issues" related to global challenges and innovation that require more analysis. For example, countryspecific environmental requirements can lead to market fragmentation and thus work against economies of scale that are needed to make "clean technologies" more competitive, yet harmonising environmental standards internationally constitutes a challenge for governments who wish to retain sovereignty over standards in their jurisdictions (OECD 2008k). Participants in a recent workshop on sustainable materials management recognised that consumption and production decisions made in other countries will increasingly have more impact on environmental results than domestic policies, and "front-runner" firms were increasingly interested in international co-operation on innovation activities (OECD 2008m).

A further question that has interested policy makers for some time is that of "free riding". With knowledge increasingly global, firms or countries can benefit from research carried out elsewhere without contributing to costs (OECD 2001b). Nevertheless, this should not deter governments from funding research - countries need their own R\&D to understand and absorb knowledge developed abroad, to become part of innovation networks and to develop their own skills. Moreover, R\&D can give first-mover advantages. Free riding is an inevitable consequence of the non-proprietary character of fundamental knowledge. Any excessive free riding, where it exists, can be reduced by sharing the costs of large scientific projects internationally - although exactly how this is done most effectively remains a challenge.

\section{Innovation in developing countries}

Innovation may be able to be harnessed more effectively to support economic development in nonOECD countries. An important idea in economic development is that countries at low income levels may be able to grow faster than those at high income levels, since they can use the technology already developed by the latter (OECD 1999a). But this "catch-up" depends heavily on two factors: social capability (in particular, an appropriate institutional framework, government capability in economic policymaking, and technological and skill levels in the population) and technological congruence (the suitability of technology from high income countries for use in follower countries). Once catch-up potential is exhausted, countries will need to expand their indigenous science and technology base. Another important idea is that a lack of vested interest in existing technology may allow developing countries to take advantage of new technologies through "leapfrogging", or the deployment of advanced technologies in developing countries ahead of their deployment in developed countries. This, for example, is the case in the petrochemical industry, where a large number of the most up to date, large scale plants can be found in developing countries in the Middle East and South East Asian countries. In both cases, however, factors such as macroeconomic stability, political stability, basic infrastructure such as communications, electricity and transportation, and the supply of human resources and capital are critical for deploying existing or new technologies.

The OECD has an increasing body of work relating to innovation in non-member countries, stemming from targeted reviews of innovation policy in selected countries and broader economic surveys. The work highlights that, while there are a number of critical policy areas that are common to all countries (such as improving framework conditions, IPR, science-industry linkages and competition), the details differ according to country characteristics and stage of development. Examples of specific policy recommendations for selected countries are given in box 7 . 


\section{Box 7. OECD innovation policy recommendations for non-member countries}

\section{Brazil}

A study of innovation in Brazil found that the main challenge for innovation policy was to encourage the business sector to engage in productivity-enhancing innovation activities (Brito Cruz \& Mello, 2006). Total R\&D spending is relatively low compared to the OECD average and the bulk of R\&D is carried out by the government, with most scientists working in public universities and research institutions. While Brazil's share of world scientific articles is as high as that of Sweden, patenting is low and process, rather than product, innovations account for the bulk of innovative activity in the business sector. One major hurdle for improving the generation and diffusion of innovation is Brazil's level of educational attainment at the tertiary level - a rapid expansion in enrolment in upper-secondary education in recent years should help, but it will take time and follow-through is essential.

The main policy recommendations for Brazil included: strengthening the framework conditions for innovation, particularly by reducing the domestic tax burden on capital and ICT goods and eliminating tariffs on capital goods and intermediate inputs to facilitate access to technology; facilitating more R\&D co-operation between universities and business; improving co-operation between federal and state agencies involved in S\&T policy and funding; making higher education curricula more attuned to market demands and increasing the availability of ICT equipment; conducting impact assessments of tax instruments; and introducing alternative support instruments, such as risksharing, matching grants and loan subsidisation, which may be more applicable to start-ups.

\section{Chile}

Innovation - underpinned by favorable framework conditions and stimulated by an explicit innovation policy could be a major route for Chile to improve its productivity performance, achieve sustainable, high and equitable growth and reduce poverty (OECD 2007l). However, Chile's national innovation system suffers from some strong imbalances and bottlenecks, which hamper performance, reduce returns on R\&D investment and slow capacity building. The business sector plays a modest role in financing and performing R\&D; most R\&D is financed by the government and is carried out in universities. Industry-science linkages are low and there is a shortage of specialised human resources.

The review of Chile's innovation policy recommended: securing a greater supply of qualified people, particularly by improving access to higher education, providing an effective system of vocational training, and ensuring degree programmes meet the needs of companies; giving more attention to the early stage of capacity building in SMEs and to the obstacles encountered by innovative SMEs in stages such as concept-to-prototype, industrialisation and commercialisation; reducing overlaps in public support and achieving critical size for individual instruments; and ensuring a clear distinction between policy formulation and implementation.

\section{China}

The recent review of innovation policy in China (OECD 2008a) concluded that fostering innovation would play a major role in China's transition to sustainable development. China has successfully mobilised resources for S\&T and these have contributed significantly to rapid socioeconomic progress; however, the spending has yet to translate into a proportionate increase in innovation performance. One reason is that the capabilities for making productive use of the investment in R\&D, human resources and infrastructure have developed more slowly, particularly in the business sector.

The review made recommendations to the Chinese authorities in two key areas: improving framework conditions for innovation; and adjusting and enhancing dedicated policies to promote S\&T. Some specific recommendations included: encouraging changes in the attitudes and methods of work of government officials so as to allow market forces, competition and the private sector to have a greater role; improving the enforcement of IPR; fostering open and efficient capital markets; providing incentives for businesses to invest in training; ensuring policies avoid "hightechnology myopia", by paying more attention to traditional industries and the service sector; and creating an interagency co-ordinating mechanism at the central government level to improve co-ordination across agencies and levels of government.

\section{Russia}

Russia's innovation potential is probably greater than that of most other countries at comparable levels of GDP per capita (Gianella \& Tompson, 2007). It benefits from a substantial science base and a well developed education system in S\&T. Yet indicators of actual innovation activity remain weak - as such, closing the gap between the amount of resources dedicated to knowledge creation, and the observed outputs in terms of innovation, is Russia's major challenge. Part of this will require stimulating greater private sector involvement in R\&D and innovation.

In terms of policy recommendations, these fell in three main areas: improving framework conditions; reforming the state science sector; and formulating appropriate interventions in S\&T. An important point was that the impact of specific interventions aimed at correcting market failures depends crucially on the capacities of the public bodies 
charged with implementing them and the quality of the overall environment. While the objectives of innovation policy are no different to those in OECD countries, the specific actions required need to reflect Russian conditions. Policy recommendations included: making progress in reducing corruption and reforming public administration; improving openness to foreign knowledge; strengthening competition; providing greater protection for IPRs, as well as more efficient specification and assignment; shifting to more competitive and project-based allocation of funding in the state science sector; reorganising, consolidating and downsizing the state science sector; reducing fiscal disincentives to innovation; and rigorously evaluating interventions, particularly the Special Economic Zones created under a 2005 law.

Tertiary education plays a vital role in improving local skills and expanding the indigenous science base. However, some countries lack the domestic capacity to meet demand for tertiary study, while others could benefit from foreign experience and knowledge to improve the quality of the tertiary education system. Cross border education, encompassing student mobility, and mobility of programmes and providers/institutions, can help to quickly expand a tertiary education system and increase a country's stock of human capital and should be considered as part of capacity development activities in developing countries (OECD/IBRD 2007). While student mobility is already relatively established and has shown to increase capacity, there is scope for further mobility of programmes and institutions, supported by appropriate quality assurance procedures. Commercial provision of cross border education may allow the building of capacity more quickly than with domestic or development assistance resources only and may grant receiving countries more negotiating power to dictate their conditions (OECD 2004b). As open educational resources are increasingly offered in non-English languages and based on non-Western cultures, they too may help to increase human capital in developing countries (OECD 2007e).

Country circumstances, however, will determine the ability of individuals and the state to generate private and social benefits from higher education. This is a challenge in the developing world, where failure to create opportunities can result in an outflow of skilled individuals, which can be aggravated by selective immigration and research funding policies in receiving countries that attract the top talent. While gains accrue to sending countries from the knowledge flows from their diaspora abroad, some returns are better captured with return flows of migrants. Return flows can increase if economic opportunities for the highly skilled expand in sending countries, leading to either permanent return, or temporary return (socalled "brain circulation"). However, this is not easy and takes time. The economic development of China and India has created opportunities for return migration. But this success has been the result of globalisation and the expansion of trade as well as of key investments in education and infrastructure. Contemporary India's specialisation in IT education and production dates from the development of the Indian Institutes of Technology (IITs) in the 1950s. Similarly, Brazil's development of world competitive aeronautics industry dates back from the establishment of an aeronautics institute in the 1940s.

For countries at very low levels of development, improving agricultural productivity is one area where R\&D and innovation could make a significant difference. Agricultural productivity in less developed countries is very low, for many reasons. This has long been a problem, but with rising food prices, many more people are much more aware of its importance. Major investments in R\&D of various types, in particular to improve farm productivity and to address causes of climate change, are needed. There is considerable evidence of underinvestment in agricultural $\mathrm{R} \& \mathrm{D}$, despite potentially huge payoffs - but these investments take a long time to affect productivity levels on farms and may not be made by poor countries themselves. Developed economies have been the traditional source of R\&D investment and innovation, and both direct investments in developing countries and transfer of relevant technologies to developing countries have a role to play. 


\section{REFERENCES}

Aghion, P., N. Bloom, R. Blundell, R. Griffith \& P. Howitt (2005), "Competition and Innovation: An Inverted-U Relationship”, Quarterly Journal of Economics 120, pp. 701-28, May.

Bassanini, A. \& Ernst, E. (2002), "Labour market institutions, product market regulation and innovation: Cross-country evidence", OECD Economics Department Working Papers, No. 316, OECD, Paris.

Brito Cruz, C. de \& Mello, L. de (2006), "Boosting Innovation Performance in Brazil", OECD Economics Department Working Papers, No. 532, OECD, Paris.

Gianella, C. \& Tompson, W. (2007), "Stimulating Innovation in Russia: The role of institutions and policies", OECD Economics Department Working Papers, No. 539, OECD, Paris.

Guellec, D. \& van Pottelsberghe de la Potterie, B. (2001), "R\&D and Productivity Growth: Panel Data Analysis of 16 OECD Countries", OECD STI Working Papers, 2001/3, OECD, Paris.

Jaumotte, F. \& Pain, N. (2005a), "An overview of public policies to support innovation", OECD Economics Department Working Papers, No. 456, OECD, Paris.

Jaumotte, F. \& Pain, N. (2005b), "Innovation in the Business Sector", OECD Economics Department Working Papers, No. 459, OECD, Paris.

Jaumotte, F. \& Pain, N. (2005c), "From ideas to development: The determinants of R\&D and patenting", OECD Economics Department Working Papers, No. 457, OECD, Paris.

Jean, S., Causa, O., Jimenez, M. \& Wanner, I. (2007), "Migration in OECD Countries: Labour Market Impact and Integration Issues", OECD Economics Department Working Papers, No. 562, OECD, Paris.

M. Khan and K. B. Luintel (2006), "Sources of Knowledge and Productivity: How Robust is the Relationship?", STI Working Paper 2006-6, OECD, Paris.

OECD (1998a), The OECD Jobs Strategy: Technology, Productivity and Job Creation, (Chapter 11: High Performance Workplaces and Intangible Investment, pp. 271-301), OECD, Paris.

OECD (1998b), The OECD Jobs Strategy: Fostering Entrepreneurship, OECD, Paris.

OECD (1999a), Managing National Innovation Systems, OECD, Paris.

OECD (1999b), "Regulatory Reform and SMEs: Concluding Note", OECD internal working document, 5 May, Paris.

OECD (2000a), A New Economy? The changing role of innovation and information technology in growth, OECD, Paris.

OECD (2000b), Knowledge Management in the Learning Society, OECD, Paris.

OECD (2001a), Innovation and Productivity in Services, OECD, Paris.

OECD (2001b), The New Economy: Beyond the Hype. The OECD Growth Project, OECD, Paris.

OECD (2001c), Innovative Clusters: Drivers of National Innovation Systems, OECD, Paris.

OECD (2001d), Cities and Regions in the New Learning Economy, OECD, Paris.

OECD (2001e), Learning to Change: ICT in Schools, OECD, Paris.

OECD (2001f), The Wellbeing of Nations: The role of human and social capital, OECD, Paris.

OECD (2002a), Benchmarking Industry-Science Relationships, OECD, Paris. 
OECD (2003a), Governance of Public Research: Towards better practices, OECD, Paris. Paris.

OECD (2003b), Measuring Knowledge Management in the Business Sector: First Steps, OECD,

OECD (2003c), Knowledge Management: New Challenges for Educational Research, OECD, Paris.

OECD (2003d), Entrepreneurship and Local Economic Development: Programme and policy recommendations, OECD, Paris.

OECD (2003e), The Sources of Economic Growth in OECD Countries, OECD, Paris.

OECD (2003f), "Merger Review in Emerging High Innovation Markets", OECD internal working document, 24 January, Paris. Paris.

OECD (2004a), The Economic Impact of ICT: Measurement, Evidence and Implications, OECD,

OECD (2004b), Internationalisation and Trade in Higher Education: Opportunities and Challenges, OECD, Paris.

OECD (2004c), Innovation in the Knowledge Economy: Implications for education and learning, OECD, Paris.

OECD (2005a), E-Learning in Tertiary Education: Where do we stand?, OECD, Paris.

OECD (2005b), Governance of Innovation Systems: Volume 1: Synthesis Report, OECD, Paris.

OECD (2005c), Innovation Policy and Performance: A Cross-Country Comparison, OECD, Paris.

OECD (2005d), "Intellectual Property Rights", OECD internal working document, 21 January, Paris.

OECD (2005e), "Promoting Innovation in Services", OECD internal working document, 14 October, Paris.

OECD (2005f), "Public-Private Partnerships for Innovation: Synthesis Report", OECD internal working document, 26 May, Paris.

OECD (2006a), Economic Policy Reforms: Going for Growth 2006, OECD, Paris.

OECD (2006b), OECD in Figures 2006-2007, OECD Paris.

OECD (2006c), Innovation in Energy Technology: Comparing National Innovation Systems at the Sectoral Level, OECD, Paris.

OECD (2006d), Innovation in Pharmaceutical Biotechnology: Comparing National Innovation Systems at the Sectoral Level, OECD, Paris.

OECD (2006e), OECD Information Technology Outlook 2006, OECD, Paris.

OECD (2006f), The SME Financing Gap: Volume 1: Theory and evidence, OECD, Paris.

OECD (2006g), Trading Up: Economic Perspectives on Development Issues in the Multilateral Trading System, OECD, Paris.

OECD (2007a), OECD Science, Technology and Industry Scoreboard 2007, OECD, Paris.

OECD (2007b), Science, Technology and Innovation Indicators in a Changing World: Responding to Policy Needs, OECD, Paris. Paris.

OECD (2007c), Higher Education and Regions: Globally Competitive, Locally Engaged, OECD,

OECD (2007d), Competitive Regional Clusters: National Policy Approaches, OECD, Paris. 

Paris.

OECD (2007e), Giving Knowledge for Free: The emergence of open educational resources, OECD,

OECD (2007f), Globalisation and Regional Economies: Can OECD Regions Compete in Global Industries?, OECD, Paris.

OECD (2007g), Environment Policy and Corporate Behaviour, Edited by Nick Johnstone, OECD, Paris.

OECD (2007h), Evidence in Education: Linking Research and Policy, OECD, Paris. Paris.

OECD (2007i), Human Capital: How what you know shapes your life, OECD Insights series, OECD,

OECD (2007j), PISA 2006: Science Competencies for Tomorrow's World: Volume 1, OECD, Paris.

OECD (2007k), Participative Web and User-Created Content: Web 2.0, Wikis and Social Networking, OECD, Paris.

OECD (20071), OECD Reviews of Innovation Policy: Chile, OECD, Paris.

OECD (2007m), "Impacts of Environmental Policy Instruments on Technological Change", OECD internal working document, 7 February, Paris.

OECD (2007n), "Dynamic Efficiencies in Merger Analysis", OECD internal working document, 15 May, Paris.

OECD (2007o), "ICTs and Environmental Challenges: Scoping outline", OECD internal working document, 20 November, Paris.

OECD (2007p), "Collaborative Mechanisms for Intellectual Property Rights", OECD internal working document, 13 February, Paris.

OECD (2007q), "Competition Assessment Toolkit", OECD internal working document, 26 September, Paris.

OECD (2007r), "Skills by industry database (ANSKILL): Contents, major trends and issues for further investigation", OECD internal working document, 12 November, Paris.

OECD (2007s), OECD Framework for the Evaluation of SME and Entrepreneurship Policies and Programmes, OECD, Paris.

OECD (2008a), OECD Review of Innovation Policy: China, OECD, Paris.

OECD (2008b), "Tax and Economic Growth”, OECD internal working document, 25 February, Paris.

OECD (2008c), "Competition, Patents and Innovation", OECD internal working document, 8 January, Paris.

OECD (2008d), "Competition Assessment Toolkit: Draft Revision", OECD internal working document, 15 February, Paris.

OECD (2008e), "Intellectual Assets and Value Creation: Draft Synthesis Report", OECD internal working document, 13 March, Paris.

OECD (2008f), "Sustainable Manufacturing and Eco-innovation: Some preliminary thoughts", OECD internal working document, 12 March, Paris.

OECD (2008g), "Expert Workshop on Knowledge Markets", OECD internal working document, 5 February, Paris.

OECD (2008h), "Measuring and Analysing Public Support to Innovation", OECD internal working document, 3 June, Paris. 
OECD (2008i), "Report on the TIP workshop of R\&D tax treatment in OECD countries: comparisons and evaluations", OECD internal working document, 26 May, Paris.

OECD (2008j), “Tax and Economic Growth”, OECD internal working document, 22 February, Paris.

OECD (2008k), "Environmental Innovation and Global Markets", OECD internal working document, 22 February, Paris.

OECD (20081), "Environmental Innovation in China", OECD internal working document, 20 February, Paris.

OECD $(2008 \mathrm{~m})$, "Draft report on the $2^{\text {nd }}$ Workshop on Sustainable Materials Management", OECD internal working document, April, Paris.

OECD (2008n), "NESTI-WPIA Innovation microdata project: Exploring non-technological and mixed modes of innovation across countries", OECD internal working document, 22 May, Paris.

OECD (2008o), "Fostering Entrepreneurship for Innovation", OECD internal working document, March, Paris.

OECD (2008p), "HGSMEs, innovation, intellectual assets and value creation", OECD internal working document, 28 April, Paris.

OECD (2008q), Open Innovation in Global Networks, OECD, Paris.

OECD (2008r), The Global Competition for Talent: Mobility of the Highly Skilled, OECD, Paris.

OECD (2008s), OECD Science, Technology and Industry Outlook, OECD, Paris.

OECD (2008t), The Internationalisation of Business R\&D: Evidence, Impacts and Implications, OECD, Paris.

OECD (2008u), Environmental Policy, Technological Innovation and Patent Activity, OECD, Paris.

OECD (2008v forthcoming), An OECD Framework for Effective and Efficient Environmental Policies, OECD, Paris. Paris.

OECD (2008w forthcoming), Strategies for Eco-Innovation: Preliminary Review of Trends, OECD,

OECD (2008x forthcoming), Trade and Innovation, OECD, Paris.

OECD \& European Communities (2005), Oslo Manual: Guidelines for collecting and interpreting innovation data, $3^{\text {rd }}$ edition, Joint Publication of the OECD and the Statistical Office of the European Communities.

OECD \& IBRD/World Bank (2007), Cross-border Tertiary Education: A Way towards Capacity Development, Paris.

Park, W. G. and D. C. Lippoldt (2008), "Technology Transfer and the Economic Implications of the Strengthening of Intellectual Property Rights in Developing Countries", OECD Trade Policy Working Papers, No. 62, OECD, Paris. 